Article

\title{
Foliar Calcium Corrects a Deficiency Causing Green Fruit Drop in 'Draper' Highbush Blueberry (Vaccinium corymbosum L.)
}

\author{
Eric Martin Gerbrandt ${ }^{1, *}$, Charles Mouritzen ${ }^{2}$ and Mark Sweeney ${ }^{3}$ \\ British Columbia Blueberry Council, \#275-32160 South Fraser Way, Abbotsford, BC V2T 1W5, Canada \\ Southwest Crop Consulting, Chilliwack, BC V2R 5G2, Canada; macmour@shaw.ca \\ British Columbia Ministry of Agriculture, Abbotsford, BC V3G 2M3, Canada; markesweeney55@gmail.com \\ * Correspondence: emg690@mail.usask.ca; Tel.: +1-604-308-0748
}

Received: 5 March 2019; Accepted: 21 March 2019; Published: 24 March 2019

check for updates

\begin{abstract}
Draper' northern highbush blueberry (Vaccinium corymbosum L.) is a widely-planted mid-season cultivar with excellent fruit quality. Under the climatic conditions of Southwestern British Columbia, Canada, and Northwestern Washington, USA, it expresses a physiological disorder causing spontaneous green fruit drop (GFD) of up to half of the developing crop just prior to onset of the fruit coloring phenophase. Reduction of economic losses due to GFD required identification of the cause of this disorder and development of an agronomic solution that would reduce fruit drop. In 2014, two initial experiments were conducted to compare three foliar Ca products under a range of $\mathrm{N}$ fertilization rates. In 2015 and 2016, three locations were used in a first step to optimizing rates and timings of foliar $\mathrm{Ca}$ application. Initial experiments determined that higher $\mathrm{N}$ fertilization rates exacerbate GFD but that foliar Ca corrects the condition. Multi-site, multi-year trials identified key rates and timings for foliar $\mathrm{Ca}$ application to provide an agronomic solution for commercial growers. These trials identified an acute fruit Ca deficiency as the cause of GFD, and that foliar calcium applied frequently at high concentration from mid-bloom onward can be effective in reducing GFD, often to negligible levels. This condition has now been reported in several production regions around the world.
\end{abstract}

Keywords: application rate; application timing; calcium chloride; calcium deficiency; efficacy trial

\section{Introduction}

'Draper' highbush blueberry (Vaccinium corymbosum L.) was developed by the Michigan State University breeding program released in 2003 [1]. Though its genetic background is primarily comprised of the northern highbush blueberry species, $V$. corymbosum, its pedigree also has contributions from southern highbush blueberry species, V. tenellum, V. ashei and V. darrowi [1]. While 'Draper' is recommended for northern production regions based on a sufficiently high chilling requirement, producers in the Fraser Valley, British Columbia (BC), Canada have found that it requires a higher level of horticultural management (e.g., preventative sprays for fungal canker) in comparison to other standard cultivars [2].

'Draper' has large, firm fruit with a strong waxy cuticle and ripens just prior to 'Bluecrop', the primary mid-season cultivar in $\mathrm{BC}$ and many other production regions [3]. With superior flavor to the primary early-season cultivar ('Duke'), relatively loose clusters, excellent firmness, and a long shelf-life, the fruit have a concentrated ripening period and can be hand- or machine-harvested [1,3]. Contrasting with these outstanding fruit quality characteristics, a 2012 survey of field performance for 'Draper' and other new cultivars identified several production challenges, the most economically 
damaging being the pervasive incidence of green fruit drop (GFD) [2]. Affecting $5-50 \%$ of the crop, depending on the field, GFD is characterized by spontaneous drop of green fruit between the end of June and the beginning of July as the first fruit begin to turn blue [4]. The fruit drop over the course of one or two weeks, and they appear normal on the exterior, contain white developing seeds within brown decaying internal tissues [4].

In 2014, this cultivar-specific phenomenon had not been observed in other production regions, and it did not present the typical etiology of a new pest or pathogen. It occurred to varying degrees within and across fields and years with increased severity under high plant vigor. These observations, combined with the low transpiration conditions preceding onset of drop, indicated similarities to other Ca deficiencies such as blossom end rot in tomato (Solanum lycopersicum L.) and bitter pit in apples (Malus pumila Miller) [5-7]. In Oregon, relative to other cultivars, 'Draper' showed low fruit Ca and high leaf Ca [8].

$\mathrm{Ca}$ is an essential plant macronutrient required for maintaining cell wall and membrane integrity, facilitating intracellular communication and controlling vacuolar osmotic balance [9]. Low soil $\mathrm{pH}$ environments have low Ca availability [10], but blueberry is a calcifuge, being adapted to an optimal pH range between 4.5-5.5 where Ca availability is limited [11]. Though some symplastic uptake of Ca occurs, most uptake is apoplastic, occurring mostly through the newest roots [12], requiring active root extension to access relatively immobile soil $\mathrm{Ca}$ and the rate of $\mathrm{Ca}$ uptake depending on the rate of transpiration $[10,13]$. In strawberry (Fragaria $\times$ ananassa Duch.) and tomato, Ca transport depends on positive pressure in the xylem [14,15]. In general, there is very limited re-mobilization of Ca from leaves to fruit by the phloem in most crops, meaning that adequate supply of Ca via the xylem to the fruit at key loading stages is critical for normal fruit development [16]. Compared to blueberry leaves, the fruit accumulate (i.e., load) $\mathrm{Ca}$ in limited concentrations but do so primarily during early developmental stages, which is also observed in other crops $[17,18]$. Consequently, conditions of low transpiration that reduce fruit Ca loading can result in localized Ca deficiencies when initial Ca concentrations are diluted during fruit sizing [19]. This is related to competition between low-transpiring fruit and high-transpiring leaves, but the role of cation balance for cation exchange sites is also important and the underlying mechanisms of Ca deficiencies are not fully understood [20].

Foliar application of Ca can be effective in correcting acute deficiencies in susceptible cultivars of other crops, while uptake, allocation, and movement of $\mathrm{Ca}$ can be modulated by cultural practices such as reduced $\mathrm{N}$ management or application of exogenous plant growth regulators [7,21-23]. Previous work on application of foliar Ca has shown mixed results in blueberry, resulting in increased fruit $\mathrm{Ca}$ concentration and influencing fruit quality under some conditions [24-26] and having no significant effects in others $[27,28]$. Correction of GFD in 'Draper' using foliar applications is not reported in the literature. The objective of this study was to identify the role of Ca deficiency in GFD and determine key foliar Ca application rates and timings to reduce yield losses to negligible levels.

\section{Materials and Methods}

In 2014, two preliminary trials were conducted in a 2008 commercial planting of 'Draper' in Abbotsford, $\mathrm{BC}$ to evaluate the effect of foliar Ca products under high vigor conditions (Experiment 1 ) and under low vigor conditions with variable rates of granular $\mathrm{N}$ fertilization (Experiment 2). In 2015 and 2016, comparison of foliar Ca application rates and timings was conducted across three sites (Experiment 3), using separate sections of the same field used in the previous year (Site 1), another 2008 planting in Abbotsford (Site 2) and a 2009 planting in Langley (Site 3). Soil types were a Lynden gravelly silt loam, Lynden silt loam and Everett gravelly sandy loam for Sites 1, 2, and 3, respectively [29].

For Experiment 1, a section of the field at Site 1 was top-dressed with non-composted broiler chicken manure on 20-May, which is routine practice for the collaborating grower but not a common production practice in the region. The rate of manure was calculated to deliver approximately $75 \mathrm{~kg} \mathrm{~N} \cdot \mathrm{Ha}^{-1}$. Manure application was withheld from the section of field used for Experiment 2 
to facilitate evaluation of the effects of foliar Ca under a range of granular $\mathrm{N}$ treatments. For both experiments, randomized complete block designs with four replications were used to compare treatments applied to five-plant plots with one-plant buffers between plots. Experiment 1 compared three Ca products (Terralink Horticulture Ltd., Abbotsford, BC, Canada) at various rates with a no-spray control: DowFlake ${ }^{\mathrm{TM}} \mathrm{Xtra}\left(83-87 \% \mathrm{CaCl}_{2} \cdot 4 \mathrm{H}_{2} \mathrm{O}\right)$ calcium chloride $\left(\mathrm{CaCl}_{2}\right)$, TigerClaw Power-Cal $4 \%$ calcium phosphite $\left(\mathrm{Ca}_{3}\left(\mathrm{PO}_{3}\right)_{2}\right)$, and $\mathrm{CaTs}^{\circledR} 6 \%$ calcium thiosulphate solution $\left(\mathrm{CaO}_{3} \mathrm{~S}_{2}\right)$. $\mathrm{CaCl}_{2}, \mathrm{Ca}_{3}\left(\mathrm{PO}_{3}\right)_{2}$, and $\mathrm{CaO}_{3} \mathrm{~S}_{2}$ were applied at spray concentrations of 1263,400 , and $450 \mathrm{ppm} \mathrm{Ca}$ in 500,494 , and $935 \mathrm{~L}$ water.ha ${ }^{-1}$, respectively. The latter two product rates were based on their label rates, but $\mathrm{CaCl}_{2}$ does not have a label rate in blueberry and so was calculated to emulate standard applications used in treatment of bitter pit in apple. Experiment 2 used broadcast application of granular ammonium sulphate, $\left(\mathrm{NH}_{4}\right)_{2} \mathrm{SO}_{4}$ (21-0-0-24[S]; Terralink Horticulture Ltd., Abbotsford, $\mathrm{BC}$, Canada), at four rates: $0(0-\mathrm{N}), 56(56-\mathrm{N}), 112(112-\mathrm{N})$, and $168(168-\mathrm{N}) \mathrm{kg} \mathrm{N} \cdot \mathrm{Ha}^{-1}$. An incomplete factorial design was used to compare the same foliar Ca products as in Experiment 1. Specifically, the no-spray control was evaluated under all four $\mathrm{N}$ rates, and the three foliar Ca products were only applied for the low and high $\mathrm{N}$ treatments (0-N and $168-\mathrm{N}$, respectively). Ammonium sulphate was applied to each plot by hand as a 50/50 split on 20-May and 03-June-2014. There was significant rainfall the day after and four days after the first and second applications, respectively, dissolving the fertilizer and washing it into the rootzone. Weekly foliar Ca applications were made using a 15-L backpack sprayer (Solo USA, Newport News, VA) flat fan 8004 nozzle (Teejet Technologies, Springfield, Illinois) from 20-May to 17-June-2014 at approximately $500 \mathrm{~L} \cdot \mathrm{Ha}^{-1}$ under slow drying conditions from 6:00-8:30 a.m. with no precipitation for the following eight hours or more, depending on the application date (Table 1). No other foliar or granular $\mathrm{N}$ or Ca were applied by the collaborating grower in this commercial field.

In 2015 and 2016, randomized complete block designs, each with four replications, were used to compare ten rate and timing treatment combinations across Sites 1, 2, and 3. Different sections of each field were used for each year of the trial to eliminate carry-over of experimental treatments from the previous year. A no-spray control was compared with a factorial design of four application timings and two rates of $\mathrm{CaCl}_{2}$ using TETRA Flake $\left(77 \% \mathrm{CaCl}_{2} \cdot 2 \mathrm{H}_{2} \mathrm{O}\right)$ calcium chloride (Terralink Horticulture Ltd., Abbotsford, $\mathrm{BC}$, Canada). The low $\left(\mathrm{L}-\mathrm{CaCl}_{2}\right)$ and high $\left(\mathrm{H}-\mathrm{CaCl}_{2}\right)$ rates were mixed to $1360 \mathrm{ppm}$ and 2720 ppm solutions of Ca, respectively. Signature ${ }^{\circledR}$ SST $8 \%$ Calcium (SST), a formulated foliar Ca product (Evergro, Abbotsford, BC, Canada) with a relatively high Canadian label rate, was applied at $4.9 \mathrm{~L} \cdot \mathrm{Ha}^{-1}(800 \mathrm{ppm})$ as a comparison to the factorial treatment of $\mathrm{CaCl}_{2}$ application rates and timings. Using a backpack sprayer (as described above) and $0.1 \%$ of a non-ionic surfactant, LI700 (Evergro, Abbotsford, BC, Canada), the tank mix concentration for each treatment was maintained as a constant throughout the experiment. Applications were made to run-off, resulting in variation in spray volume from 371 to $914 \mathrm{~L}$ water. $\mathrm{Ha}^{-1}$, depending on plant size and crop development stage across sites and application timings (Table 1 ). $\mathrm{L}-\mathrm{CaCl}_{2}$ and $\mathrm{H}-\mathrm{CaCl}_{2}$ were applied three times at weekly intervals, and there was an overlapping week between early (Early), middle (Mid), and late (Late) timing treatments. A fourth application timing (All) overlapped the seven application timings from Early to Late timing. SST was applied at Mid timing only. Dates and plant phenological stages for these applications varied across locations and years, starting as early as $40 \%$ of open flowers for the Early timing to three or four weeks into green fruit development for the Late and All timings. 
Table 1. Dates, plant phenological stages and foliar Ca application spray volumes made to 'Draper' highbush blueberry across three farm sites in the Fraser Valley, British Columbia, Canada in 2015 and 2016.

\begin{tabular}{|c|c|c|c|c|c|c|c|}
\hline \multicolumn{4}{|c|}{ Date } & \multicolumn{2}{|c|}{ Phenology } & \multicolumn{2}{|c|}{ Spray Volume $\left(\mathrm{L} \cdot \mathrm{ha}^{-1}\right)$} \\
\hline Timings & 2015 & 2016 & Site & 2015 & 2016 & 2015 & 2016 \\
\hline \multirow{3}{*}{ Early, All } & \multirow{3}{*}{ 22-April } & \multirow{3}{*}{ 26-April } & 1 & $70 \%$ bloom; $10 \%$ petal fall & $80 \%$ bloom; $5 \%$ petal fall & 494 & 549 \\
\hline & & & 2 & $50 \%$ bloom; $0 \%$ petal fall & $60 \%$ bloom; $0 \%$ petal fall & 371 & 504 \\
\hline & & & 3 & $30 \%$ bloom; $0 \%$ petal fall & $40 \%$ bloom; $0 \%$ petal fall & 371 & 413 \\
\hline \multirow{3}{*}{ Early, All } & \multirow{3}{*}{ 2-May } & \multirow{3}{*}{ 3-May } & 1 & $100 \%$ bloom; $40 \%$ petal fall & $100 \%$ bloom; $40 \%$ petal fall & 494 & 596 \\
\hline & & & 2 & $95 \%$ bloom; $25 \%$ petal fall & $100 \%$ bloom; $15 \%$ petal fall & 371 & 549 \\
\hline & & & 3 & $60 \%$ bloom; $5 \%$ petal fall & $90 \%$ bloom; $5 \%$ petal fall & 371 & 504 \\
\hline \multirow{3}{*}{ Early, Mid, All } & \multirow{3}{*}{ 9-May } & \multirow{3}{*}{ 10-May } & 1 & $100 \%$ bloom; $80 \%$ petal fall & $100 \%$ petal fall & 556 & 731 \\
\hline & & & 2 & $100 \%$ bloom; $60 \%$ petal fall & $95 \%$ petal fall & 494 & 670 \\
\hline & & & 3 & $95 \%$ bloom; $25 \%$ petal fall & $90 \%$ petal fall & 432 & 640 \\
\hline \multirow{3}{*}{ Mid, All } & \multirow{3}{*}{ 16-May } & \multirow{3}{*}{ 17-May } & 1 & $100 \%$ petal fall & Green fruit & 618 & 731 \\
\hline & & & 2 & $100 \%$ petal fall & Green fruit & 556 & 640 \\
\hline & & & 3 & $100 \%$ bloom; $70 \%$ petal fall & Green fruit & 556 & 640 \\
\hline \multirow{3}{*}{ Mid, Late, All } & \multirow{3}{*}{ 23-May } & \multirow{3}{*}{ 24-May } & 1 & Green fruit & Green fruit & 618 & 853 \\
\hline & & & 2 & Green fruit & Green fruit & 556 & 793 \\
\hline & & & 3 & $100 \%$ petal fall & Green fruit & 556 & 731 \\
\hline \multirow{3}{*}{ Late, All } & \multirow{3}{*}{ 30-May } & \multirow{3}{*}{ 31-May } & 1 & Green fruit & Green fruit & 803 & 914 \\
\hline & & & 2 & Green fruit & Green fruit & 741 & 823 \\
\hline & & & 3 & Green fruit & Green fruit & 618 & 731 \\
\hline \multirow{3}{*}{ Late, All } & \multirow{3}{*}{ 06-Jun } & \multirow{3}{*}{ 06-Jun } & 1 & Green fruit & Green fruit & 803 & 914 \\
\hline & & & 2 & Green fruit & Green fruit & 741 & 823 \\
\hline & & & 3 & Green fruit & Green fruit & 618 & 731 \\
\hline
\end{tabular}


In each experiment, the central three plants from each plot were used for data collection. For Experiments 1 and Experiment 2, 50-fruit samples were taken from each plot at three times during the ripe fruit stage on 9-, 21-, and 28-July to calculate a weighted average fruit weight (1:2:1 between first, second and third samples, respectively). Three subsamples of ripe fruit were taken for each of the four replicates for the no-spray control and $\mathrm{CaCl}_{2}$ treatment under both the lowest $(0-\mathrm{N})$ and highest (168-N) vigor conditions in Experiment 2, and these were washed with distilled water and subjected to chemical nutrient analysis by a commercial laboratory (Brookside Laboratories Inc., New Bremen, OH, USA). For Experiment 3, fruit samples were taken at the green fruit stage on 19/20-June in 2015 and 16/17-June in 2016 and at the ripe fruit stage on 15-July in 2015 and 9-July in 2016. Soil samples were taken as a composite of nine cores from each plot. Cores were taken at 0-30 cm soil depth at 20-30 cm from the center of the row. Leaf samples (40-leaves per plot) were taken at the time of green fruit sampling and later in the season, on 29/30-July in 2015 and 30/31-July in 2016, as per the recommended leaf tissue sampling protocol developed in Oregon [30]. Fruit and leaf samples were weighed, washed with distilled water, dried in an oven, and then weighed again before being sent for chemical nutrient analysis (Brookside Laboratories Inc., New Bremen, OH, USA). For Experiment 3, green fruit and early leaf samples were analyzed for all treatment combinations in 2015 but only for the control in 2016, whereas ripe fruit and late leaf tissue samples were analyzed for all biological replicates of each treatment combination in both years. Chemical nutrient analysis results, reported as dry weight $(\mathrm{DW})$ values, were converted to fresh weight $(\mathrm{FW})$ values using individual sample weights before and after drying.

At the same time as ripe fruit sampling, evaluation of yield components was performed for each of the three technical replicate plants of each plot by counting: total number of clusters.plant ${ }^{-1}$, ten counts of fruit.cluster ${ }^{-1}$, and calculation of average fruit weight based on fruit samples. For Experiment 1 and Experiment 2, yield estimate after GFD was compared with estimates made prior to GFD on 16-June in 2014. While there was negligible GFD across the region in 2015, severity of fruit drop was determined in 2014 and 2016 by counting all fruit on the ground beneath the three central plants of each plot. Percent fruit drop was calculated from yield components and the number of dropped fruit.

All data were analyzed in the ' $R$ ' statistical environment [31] via linear mixed model regression using the 'lme4' package [32]. Treatments for Experiments 1 and Experiment 2 were compared via stepwise model simplification to determine the minimally adequate model with comparisons between successive models via the Akaike Information Criterion (AIC). All parameters remaining in the minimally adequate model were statistically different at $p<0.05$. For Experiment 3, multiple comparisons between treatments were made using linear contrasts extracted from regression models and pairwise comparisons using the 'multcompView' package [33] to determine statistically significant differences $(p<0.05)$.

\section{Results}

\subsection{Experiment 1}

In the manured section of the field, neither the percent fruit drop nor the estimated loss of yield were significantly reduced by $\mathrm{CaO}_{3} \mathrm{~S}_{2}$, but there was a significant $4.9 \%$ increase in estimated yield (Table 2). However, $\mathrm{Ca}_{3}\left(\mathrm{PO}_{3}\right)_{2}$ and $\mathrm{CaCl}_{2}$ reduced percent fruit drop by $22.9 \%$ and $55.9 \%$ and the estimated amount of yield loss by $26.0 \%$ and $55.6 \%$, respectively. This did not translate to significant increases in the estimated yield that was measured after GFD, indicating some compensation in yield components in response to a change in crop load under high $\mathrm{N}$ management through application of manure. There were no significant differences in fruit weight at early or late sampling dates, but foliar $\mathrm{Ca}$ treatments varied in their effect on fruit weight at the middle sampling date, $\mathrm{CaCl}_{2}$ increasing and $\mathrm{Ca}_{3}\left(\mathrm{PO}_{3}\right)_{2}$ decreasing fruit weight in comparison to the control. The average fruit weight across sampling dates was only significantly impacted by $\mathrm{CaCl}_{2}$, being slightly larger than the control. 
Table 2. Effects of foliar Ca treatments on mean \pm SE estimated fruit yield, pre-mature green fruit drop, yield loss and fruit weight in 'Draper' highbush blueberry in Abbotsford, British Columbia, Canada in 2014.

\begin{tabular}{|c|c|c|c|c|c|c|c|c|}
\hline \multicolumn{9}{|c|}{ Experiment 1} \\
\hline \multirow{2}{*}{$\begin{array}{c}\text { Calcium } \\
\text { Treatment }\end{array}$} & \multirow{2}{*}{$\begin{array}{c}\text { Nitrogen } \\
\text { Treatment } \\
\left(\mathrm{kg} \mathrm{N} \cdot \mathrm{ha}^{-1}\right)\end{array}$} & \multirow{2}{*}{$\begin{array}{l}\text { Yield Estimate } \\
\left(\mathrm{kg} \cdot \mathrm{ha}^{-1}\right)^{5}\end{array}$} & \multirow{2}{*}{ Fruit Drop (\%) } & \multirow{2}{*}{$\begin{array}{l}\text { Yield Loss Estimate } \\
\qquad\left(\mathrm{kg} \cdot \mathrm{ha}^{-1}\right)\end{array}$} & \multicolumn{4}{|c|}{ Average Fruit Weight (g/fruit) } \\
\hline & & & & & Early & Mid & Late & Average \\
\hline Control & \multirow{4}{*}{$\begin{array}{l}\text { Poultry } \\
\text { manure }\end{array}$} & $10,004 \pm 474 a$ & $16.1 \pm 1.4 \mathrm{c}$ & $1613 \pm 159 c$ & $1.8 \pm 0.1 \mathrm{a}$ & $1.9 \pm 0.0 \mathrm{~b}$ & $1.8 \pm 0.1 \mathrm{a}$ & $1.9 \pm 0.0 \mathrm{a}$ \\
\hline $\mathrm{CaCl}_{2} 1$ & & $9946 \pm 176 a$ & $7.2 \pm 0.9 a$ & $716 \pm 81 a$ & $1.7 \pm 0.1 \mathrm{a}$ & $2.2 \pm 0.1 \mathrm{c}$ & $1.8 \pm 0.0 \mathrm{a}$ & $2.0 \pm 0.1 b$ \\
\hline $\mathrm{Ca}_{3}\left(\mathrm{PO}_{3}\right)_{2}{ }^{2}$ & & $9579 \pm 250 a$ & $12.4 \pm 0.8 \mathrm{~b}$ & $1194 \pm 91 b$ & $1.8 \pm 0.1 \mathrm{a}$ & $1.9 \pm 0.1 \mathrm{a}$ & $1.8 \pm 0.1 \mathrm{a}$ & $1.8 \pm 0.1 \mathrm{a}$ \\
\hline $\mathrm{CaO}_{3} \mathrm{~S}_{2}{ }^{3}$ & & $10,496 \pm 336 b$ & $15.6 \pm 1.8 \mathrm{c}$ & $1635 \pm 185 c$ & $1.8 \pm 0.1 \mathrm{a}$ & $2.0 \pm 0.1 b$ & $1.8 \pm 0.0 \mathrm{a}$ & $1.9 \pm 0.1 \mathrm{a}$ \\
\hline \multicolumn{9}{|c|}{ Experiment 2} \\
\hline \multirow{4}{*}{ Control } & 0 & $12,167 \pm 1334 b$ & $13.1 \pm 1.6 \mathrm{c}$ & $1530 \pm 53 d$ & $1.9 \pm 0.1 b$ & $2.2 \pm 0.1 \mathrm{c}$ & $1.8 \pm 0.0 \mathrm{~b}$ & $2.0 \pm 0.0 \mathrm{~d}$ \\
\hline & 56 & $11,190 \pm 1233 a$ & $13.1 \pm 1.7 \mathrm{c}$ & $1408 \pm 99 d$ & $1.9 \pm 0.1 b$ & $2.2 \pm 0.0 \mathrm{~b}$ & $1.8 \pm 0.1 \mathrm{a}$ & $2.0 \pm 0.1 c$ \\
\hline & 112 & $10,998 \pm 570 a$ & $12.6 \pm 1.0 \mathrm{c}$ & $1372 \pm 73 d$ & $1.8 \pm 0.1 b$ & $2.1 \pm 0.0 \mathrm{a}$ & $1.7 \pm 0.0 \mathrm{a}$ & $1.9 \pm 0.0 \mathrm{~b}$ \\
\hline & 168 & $11,128 \pm 1245 a$ & $13.1 \pm 1.7 \mathrm{c}$ & $1431 \pm 180 \mathrm{~d}$ & $2.0 \pm 0.1 \mathrm{c}$ & $2.1 \pm 0.0 \mathrm{a}$ & $1.8 \pm 0.0 \mathrm{~b}$ & $2.0 \pm 0.0 \mathrm{c}$ \\
\hline \multirow{2}{*}{$\mathrm{CaCl}_{2}$} & 0 & $14,085 \pm 1853 c$ & $3.4 \pm 0.5 a$ & $470 \pm 65 a$ & $1.9 \pm 0.0 \mathrm{~b}$ & $2.2 \pm 0.1 b$ & $1.9 \pm 0.0 c$ & $2.0 \pm 0.0 \mathrm{~d}$ \\
\hline & 168 & $12,153 \pm 1110 b$ & $2.5 \pm 0.2 \mathrm{a}$ & $303 \pm 12 a$ & $1.7 \pm 0.1 \mathrm{a}$ & $2.0 \pm 0.0 \mathrm{a}$ & $1.8 \pm 0.1 \mathrm{a}$ & $1.9 \pm 0.0 \mathrm{a}$ \\
\hline \multirow{2}{*}{$\mathrm{Ca}_{3}\left(\mathrm{PO}_{3}\right)_{2}$} & 0 & $12,277 \pm 1332 b$ & $9.8 \pm 1.5 b$ & $1140 \pm 68 c$ & $1.9 \pm 0.1 b$ & $2.1 \pm 0.1 \mathrm{a}$ & $1.8 \pm 0.1 b$ & $2.0 \pm 0.1 c$ \\
\hline & 168 & $11,855 \pm 1006 b$ & $10.6 \pm 1.3 b$ & $1214 \pm 71 c$ & $1.9 \pm 0.0 \mathrm{~b}$ & $2.1 \pm 0.1 b$ & $2.0 \pm 0.1 c$ & $2.0 \pm 0.1 \mathrm{~d}$ \\
\hline \multirow{2}{*}{$\mathrm{CaO}_{3} \mathrm{~S}_{2}$} & 0 & $11,348 \pm 1129 a$ & $9.3 \pm 2.4 b$ & $974 \pm 175 b$ & $2.1 \pm 0.1 c$ & $2.2 \pm 0.0 \mathrm{~b}$ & $1.8 \pm 0.0 \mathrm{~b}$ & $2.1 \pm 0.0 \mathrm{~d}$ \\
\hline & 168 & $11,941 \pm 1557 \mathrm{~b}$ & $12.3 \pm 1.6 \mathrm{c}$ & $1408 \pm 87 \mathrm{~d}$ & $2.0 \pm 0.1 \mathrm{c}$ & $2.1 \pm 0.1 b$ & $1.9 \pm 0.0 \mathrm{~b}$ & $2.0 \pm 0.1 \mathrm{~d}$ \\
\hline
\end{tabular}

${ }^{1}$ DowFlake $^{\mathrm{TM}}$ Xtra $83-87 \%$ calcium chloride. ${ }^{2}$ TigerClaw Power-Cal $4 \%$ calcium phosphite. ${ }^{3} \mathrm{CaTs}^{\circledR} 6 \%$ calcium thiosulphate solution. ${ }^{4}$ Treated with approximately $75 \mathrm{~kg}$ N.ha ${ }^{-1}$, but this is not statistically comparable with other nitrogen treatments. ${ }^{5}$ Treatment combinations not connected by the same letter are statistically different $(p<0.05)$ based on stepwise model simplification of linear mixed model regression using Akaike Information Criterion to determine the minimally adequate model. 
Responses to foliar Ca varied by product. Specifically, by altering the amount of fruit retained on the bush up until the time of harvest, foliar Ca treatments had different effects on the pre-drop and post-drop yield estimates as well as average fruit weight at the time of harvest. This suggests interactions of plant vigor and crop load in response to these foliar applications. The changes in crop load that resulted from foliar Ca led to differential compensation in yield components. Plots with a greater yield estimate prior to GFD were positively correlated with greater loss of fruit $(r=0.7152$, $p<0.001)$, but the yield estimate after GFD was not correlated $(r=0.2958, p=0.2641)$ with the weight of fruit lost during GFD.

\subsection{Experiment 2}

In the section of field without spring manure application, percent fruit drop and estimated loss of yield were reduced to the greatest extent by $\mathrm{CaCl}_{2}$ treatment under high and low $\mathrm{N}$ rates and more moderately reduced by $\mathrm{Ca}_{3}\left(\mathrm{PO}_{3}\right)_{2}$ and $\mathrm{CaO}_{3} \mathrm{~S}_{2}$ (Table 2). Though no differences were noted between control plots at different $\mathrm{N}$ rates, greater effects were seen at $0-\mathrm{N}$ than at $168-\mathrm{N}$ for estimated yield in response to $\mathrm{CaCl}_{2}$ and for estimated yield, percent fruit drop and estimated yield loss in response to $\mathrm{CaO}_{3} \mathrm{~S}_{2} . \mathrm{CaCl}_{2}$ application resulted in statistically equivalent 74.0 and $80.9 \%$ reductions in percent fruit drop, for $0-\mathrm{N}$ and $168-\mathrm{N}$, respectively; and $\mathrm{Ca}_{3}\left(\mathrm{PO}_{3}\right)_{2}$ application resulted in statistically equivalent 25.2 and $19.1 \%$ reductions at $0-\mathrm{N}$ and $168-\mathrm{N}$, respectively. In contrast, the reduction in percent fruit drop for $\mathrm{CaO}_{3} \mathrm{~S}_{2}$ was statistically greater at $0-\mathrm{N}(29.0 \%)$ than at $168-\mathrm{N}(6.1 \%)$.

Whereas the impacts on estimated yield loss substantially paralleled the effects on percent fruit drop, the effects on estimated yield were more complex. In the absence of Ca applications, estimated yield was significantly higher by $8.0 \%, 9.6 \%$, and $8.5 \%$ for $0-\mathrm{N}$ than $56-\mathrm{N}, 112-\mathrm{N}$ and $168-\mathrm{N}$, respectively, these higher $\mathrm{N}$ rates having statistically equivalent yield estimate to one another. At $0-\mathrm{N}$, yield estimate was increased by $15.8 \%$ by $\mathrm{CaCl}_{2}$, was not altered by $\mathrm{Ca}_{3}\left(\mathrm{PO}_{3}\right)_{2}$ and was decreased by $6.7 \%$ by $\mathrm{CaO}_{3} \mathrm{~S}_{2}$. At $168-\mathrm{N}$, yield estimate was increased by $9.2 \%, 6.5 \%$, and $7.3 \%$ by $\mathrm{CaCl}_{2}, \mathrm{Ca}_{3}\left(\mathrm{PO}_{3}\right)_{2}$, and $\mathrm{CaO}_{3} \mathrm{~S}_{2}$, respectively. Further, $\mathrm{CaCl}_{2}$-treated plots had $13.7 \%$ lower estimated yield at $168-\mathrm{N}$ than $0-\mathrm{N}$, and $\mathrm{Ca}_{3}\left(\mathrm{PO}_{3}\right)_{2}$ plots showed no difference in estimated yield between $168-\mathrm{N}$ and $0-\mathrm{N}$, but $\mathrm{CaO}_{3} \mathrm{~S}_{2}$ plots had a $5.2 \%$ higher estimated yield at $168-\mathrm{N}$ compared to $0-\mathrm{N}$. In summary, estimated yield was greater for $\mathrm{CaCl}_{2}$ than the control at both $\mathrm{N}$ rates, and it was greater for $\mathrm{Ca}_{3}\left(\mathrm{PO}_{3}\right)_{2}$ and $\mathrm{CaO}_{3} \mathrm{~S}_{2}$ than the control at $168-\mathrm{N}$, but for $\mathrm{CaO}_{3} \mathrm{~S}_{2}$ it was lower than the control at $0-\mathrm{N}$. The statistical differences in fruit weight found between $\mathrm{Ca}$ treatments and across $\mathrm{N}$ rates varied across sampling dates without a clearly interpretable pattern.

Chemical nutrient analysis of fruit showed significantly greater $\mathrm{Ca}$ content for $\mathrm{CaCl}_{2}$ at $0-\mathrm{N}$ $(0.06 \pm 0.00 \mathrm{SE})$ and $168-\mathrm{N}(0.07 \pm 0.00 \mathrm{SE})$ than the control (both $0.04 \pm 0.00 \mathrm{SE})$, with no significant difference between $\mathrm{N}$ rates for either of the other two Ca treatments that were less effective in reducing fruit drop. There was a strong negative association between green fruit $\mathrm{Ca}$ and percent fruit drop $\left(R^{2}=\right.$ 0.9878) for control and $\mathrm{CaCl}_{2}$ treatments under high and low $\mathrm{N}$ rates (Figure 1).

As for Experiment 1, complex responses to various combinations of $\mathrm{Ca}$ and $\mathrm{N}$ rates in Experiment 2 were seen across sampling periods, suggesting differential compensation of yield components to the alterations in crop load that, in turn, resulted from reductions in fruit drop. Overall, there was lower estimated yield at higher $\mathrm{N}$ rates without $\mathrm{Ca}$ treatment, the most effective Ca treatment increased yield at both high and low $\mathrm{N}$ rates. Depending on the effectiveness of the Ca treatment, the resulting increase in estimated yield was either equivalent across $\mathrm{N}$ rates, greater at the high $\mathrm{N}$ rate or greater at the low $\mathrm{N}$ rate.

Across all treatments, estimated yield was negatively correlated with percent drop ( $r=-0.5854$, $p<0.001)$ and positively correlated with average fruit weight $(r=0.4502, p=0.0021)$. Therefore, over a range of $\mathrm{N}$ rates, there was a typical, positive relationship between fruit size and yield, and plants that dropped fewer fruit still effectively sized their fruit prior to harvest. This was observed as an increased yield estimate rather than a reduced average fruit size. This was further demonstrated by a lack of correlation between average fruit weight and percent drop $(r=-0.0399, p=0.8081)$ and total yield loss 
estimate $(r=-0.2455, p=0.1235)$. Higher yielding plants dropped a slightly lower percentage of fruit but not a lower amount of fruit overall. There was no significant relationship between estimated yield loss and the estimated yield before drop $(r=-0.0607, p=0.7116)$, but there was a significant negative correlation between percent drop and the pre-drop yield estimate $(r=-0.4280, p=0.004)$. Therefore, higher yielding plants appeared to lose a lower percentage of fruit while the overall pre-drop yield estimate was not associated with the total amount of fruit that dropped. Though plants with a greater crop load before GFD tended to lose a greater percentage of their fruit, this did not result in a significant relationship between estimated yield loss and the pre-drop yield estimate.

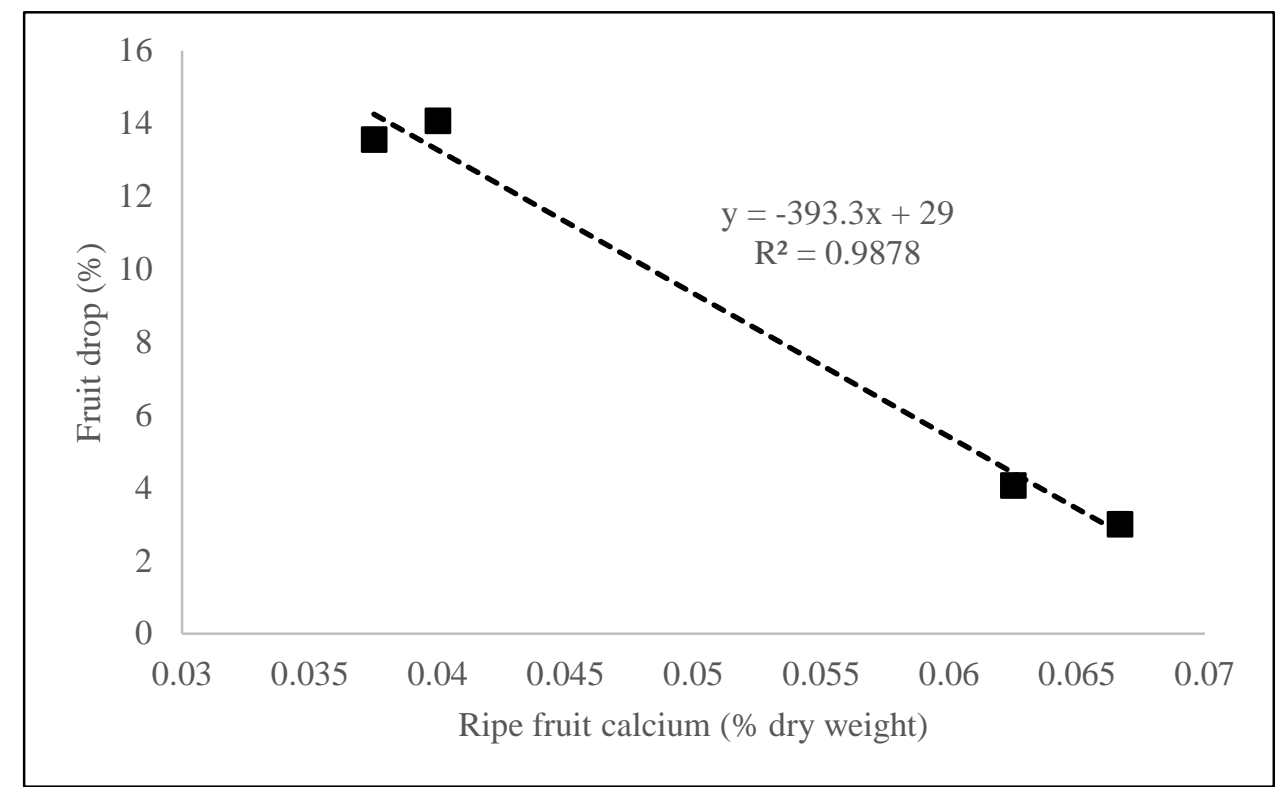

Figure 1. XY plots with regression equations and coefficients of determination between percent fruit drop and ripe fruit calcium for 'Draper' highbush blueberry treated (right) and non-treated (left) with foliar Ca under high and low nitrogen conditions on a single farm site in Abbotsford, British Columbia, Canada in 2014.

No statistical comparison could be made between the plots used for Experiments 1 and 2 in 2014, but there was a greater numerical percent fruit drop for the $\mathrm{Ca}$ control plots that received manure than the Ca control plots at any rate of supplemental $\mathrm{N}$ in the absence of manure application. Moreover, the effects of the Ca treatments were numerically smaller with manure than without manure, regardless the $\mathrm{N}$ rate. Since some of the Ca treatments were less effective under higher $\mathrm{N}$ rates, plant fertility status, and its effect on vigor, appeared to influence the ability to mitigate GFD with foliar Ca applications.

\subsection{Experiment 3}

As a result of an atypical season in 2015, with very early phenological development due to warm, dry weather conditions, GFD was very minimal across the production region in Southwestern BC and the neighboring areas of northwestern Washington. In contrast, though 2016 was also an abnormally early season, climatic conditions were conducive to the most severe GFD experienced to-date. Due to the absence of GFD in 2015, plant responses to foliar Ca applications did not show any statistical differences (data not shown); in 2016, plant responses contrasted across replicated field sites, percent fruit drop ranging from minimal at Site 3 to moderate at Site 1 to severe at Site 2 (Table 3). 
Table 3. Mean \pm SE estimated fruit yield, pre-mature green fruit drop and fruit per cluster in 'Draper' highbush blueberry in response to foliar Ca application rates and timings across three farm sites in the Fraser Valley, British Columbia, Canada in 2016.

\begin{tabular}{|c|c|c|c|c|c|c|c|c|c|c|c|}
\hline \multirow{2}{*}{ Product } & \multirow{2}{*}{ Timing } & \multirow{2}{*}{ Rate (ppm) } & \multicolumn{3}{|c|}{${\text { Estimated Fruit Yield }\left(\mathrm{kg} \cdot \mathrm{ha}^{-1}\right)^{7}}^{7}$} & \multicolumn{3}{|c|}{ Fruit Drop (\%) } & \multicolumn{3}{|c|}{ Fruit Per Cluster } \\
\hline & & & Site 1 & Site 2 & Site 3 & Site 1 & Site 2 & Site 3 & Site 1 & Site 2 & Site 3 \\
\hline SST $^{1}$ & Mid & 800 & $16,568 \pm 1709 \mathrm{ab}$ & $5252 \pm 445 \mathrm{~b}$ & $7487 \pm 2329 \mathrm{ab}$ & $12.0 \pm 0.8 \mathrm{de}$ & $8.9 \pm 3.4 \mathrm{ab}$ & $2.8 \pm 0.7 \mathrm{~b}$ & $5.8 \pm 0.1 \mathrm{ab}$ & $6.3 \pm 0.3 b c$ & $5.9 \pm 0.2 \mathrm{a}$ \\
\hline \multirow{8}{*}{$\mathrm{CaCl}_{2}{ }^{2}$} & \multirow{2}{*}{ Early ${ }^{3}$} & 1360 & $17,023 \pm 2068 \mathrm{a}-\mathrm{c}$ & $7967 \pm 576 \mathrm{~d}$ & $8809 \pm 2959 b-d$ & $8.5 \pm 3.3 \mathrm{~cd}$ & $5.6 \pm 1.8 \mathrm{a}$ & $0.8 \pm 0.4 \mathrm{a}$ & $6.3 \pm 0.4 b c$ & $7.3 \pm 0.3 \mathrm{~cd}$ & $7.0 \pm 0.1 \mathrm{~b}$ \\
\hline & & 2720 & $19,784 \pm 3229 \mathrm{c}-\mathrm{e}$ & $6655 \pm 597 c$ & $8017 \pm 2245 a-c$ & $3.5 \pm 0.5 \mathrm{ab}$ & $1.4 \pm 0.3 a$ & $0.4 \pm 0.1 \mathrm{a}$ & $6.9 \pm 0.1 \mathrm{~cd}$ & $8.0 \pm 0.4 \mathrm{~d}$ & $7.0 \pm 0.1 b$ \\
\hline & \multirow{2}{*}{$\operatorname{Mid}^{4}$} & 1360 & $20,226 \pm 2643 \mathrm{de}$ & $8645 \pm 894$ de & $8149 \pm 1745 a-c$ & $6.9 \pm 0.7 b c$ & $4.7 \pm 0.9 \mathrm{a}$ & $0.9 \pm 0.3 a$ & $7.0 \pm 0.5 \mathrm{~cd}$ & $7.8 \pm 0.7 \mathrm{~d}$ & $7.1 \pm 0.6 \mathrm{~b}$ \\
\hline & & 2720 & $17,956 \pm 2354 \mathrm{~b}-\mathrm{d}$ & $8340 \pm 423$ de & $8443 \pm 2924 a-d$ & $6.2 \pm 0.6 \mathrm{a}-\mathrm{c}$ & $1.7 \pm 0.6 \mathrm{a}$ & $0.7 \pm 0.2 \mathrm{a}$ & $6.7 \pm 0.2 \mathrm{~cd}$ & $7.7 \pm 0.3 \mathrm{~d}$ & $7.1 \pm 0.3 b$ \\
\hline & \multirow{2}{*}{ Late $^{5}$} & 1360 & $16,043 \pm 2153 \mathrm{ab}$ & $6338 \pm 337 b c$ & $7018 \pm 2123 a$ & $14.1 \pm 2.1 \mathrm{e}$ & $25.2 \pm 4.5 \mathrm{~cd}$ & $5.4 \pm 0.9 \mathrm{c}$ & $5.7 \pm 0.2 \mathrm{ab}$ & $4.8 \pm 0.2 \mathrm{a}$ & $5.9 \pm 0.2 a$ \\
\hline & & 2720 & $14,977 \pm 1931 \mathrm{a}$ & $6626 \pm 333 c$ & $8239 \pm 2738 a-c$ & $16.4 \pm 3.0 \mathrm{ef}$ & $17.4 \pm 3.9 \mathrm{bc}$ & $3.0 \pm 0.9 b$ & $5.5 \pm 0.2 \mathrm{a}$ & $5.5 \pm 0.3 \mathrm{ab}$ & $6.1 \pm 0.2 \mathrm{a}$ \\
\hline & \multirow{2}{*}{ All 6} & 1360 & $20,429 \pm 3212 \mathrm{de}$ & $9945 \pm 917 f$ & $9415 \pm 2988 \mathrm{~cd}$ & $4.2 \pm 0.6 \mathrm{a}-\mathrm{c}$ & $1.6 \pm 0.5 \mathrm{a}$ & $0.5 \pm 0.1 \mathrm{a}$ & $7.2 \pm 0.3 \mathrm{~d}$ & $8.2 \pm 0.6 \mathrm{~d}$ & $7.4 \pm 0.2 b$ \\
\hline & & 2720 & $21,245 \pm 3593 e$ & $9312 \pm 998 \mathrm{ef}$ & $10,098 \pm 3339 d$ & $2.1 \pm 0.6 \mathrm{a}$ & $0.4 \pm 0.1 \mathrm{a}$ & $0.2 \pm 0.1 \mathrm{a}$ & $7.0 \pm 0.1 \mathrm{~cd}$ & $8.1 \pm 0.7 d$ & $7.4 \pm 0.1 b$ \\
\hline Control & $\mathrm{n} / \mathrm{a}$ & 0 & $15,431 \pm 3084 a b$ & $3950 \pm 454 a$ & $8684 \pm 3219 a-d$ & $18.8 \pm 1.6 \mathrm{f}$ & $32.5 \pm 8.6 \mathrm{~d}$ & $5.3 \pm 0.7 \mathrm{c}$ & $5.4 \pm 0.4 a$ & $4.4 \pm 0.6 a$ & $6.2 \pm 0.3 a$ \\
\hline
\end{tabular}

${ }^{1}$ Signature ${ }^{\circledR} 8 \%$ Calcium Silicate. ${ }^{2}$ TETRA Flake $77 \%$ calcium chloride. ${ }^{3}$ Three weekly early applications starting at mid-bloom stage. ${ }^{4}$ Three weekly middle applications starting at end of petal fall stage. ${ }^{5}$ Three weekly late applications starting during early green fruit stage. ${ }^{6}$ Seven weekly applications spanning mid-bloom to green fruit stages. ${ }^{7}$ Treatment combinations not connected by the same letter are statistically different $(p<0.05)$ based on linear contrasts extracted from mixed regression models. 
The low severity of drop in the control plots (5.3\%) at Site 3 in Langley was observed for plants with yield estimate of $8.7 \mathrm{t} \cdot \mathrm{ha}^{-1}$ and related to a high 6.2 fruit per cluster. Foliar Ca applications reduced percent drop as low as $0.2 \%$, Early, Mid, and All timings at both $\mathrm{L}-\mathrm{CaCl}_{2}$ and $\mathrm{H}-\mathrm{CaCl}_{2}$ having statistically equivalent effects. The $\mathrm{L}-\mathrm{CaCl}_{2}$ treatment at Late timing was equivalent to the control while $\mathrm{H}-\mathrm{CaCl}_{2}$ at Late timing and SST at Mid timing were statistically intermediate. With such a low percent drop in general, no significant differences in estimated yield were detected between the control and any of the Ca treatments. In contrast, there were significant increases in fruit per cluster, as high as 7.4, for Early, Mid, and All applications of $\mathrm{L}-\mathrm{CaCl}_{2}$ and $\mathrm{H}-\mathrm{CaCl}_{2}$ with no significant effects for either rate at the Late timing or the SST treatment at Mid timing.

Under moderately severe drop of $18.8 \%$ in control plots at Site 1 in Abbotsford, almost all treatments significantly reduced percent fruit drop. The lowest percent drop was $2.1 \%$ and was observed for $\mathrm{H}-\mathrm{CaCl}_{2}$ at All timing, which was equivalent to $\mathrm{H}-\mathrm{CaCl}_{2}$ at Early and Mid timings as well as $\mathrm{L}-\mathrm{CaCl}_{2}$ at All timing. Early and Mid timings of $\mathrm{L}-\mathrm{CaCl}_{2}$ were more modest in their effects. While the impact of SST at Mid timing and $\mathrm{L}-\mathrm{CaCl}_{2}$ at Late timing were even less pronounced, $\mathrm{H}-\mathrm{CaCl}_{2}$ was not significantly different from the control at Late timing. These differences in percent drop translated to differences in estimated fruit yield with significant increases detected for $\mathrm{H}-\mathrm{CaCl}_{2}$ at Early and All timings and $\mathrm{L}-\mathrm{CaCl}_{2}$ at Mid and All timings. Fruit per cluster was increased for all Early, Mid, and All timings of $\mathrm{CaCl}_{2}$ application, but was not increased for SST or for the Late timing of $\mathrm{CaCl}_{2}$ application.

With a severe drop of $32.5 \%$ in control plots at Site 2, all treatments but Late $\mathrm{L}_{-} \mathrm{CaCl}_{2}$ significantly decreased drop. The Early, Mid, and All applications of $\mathrm{CaCl}_{2}$ and Mid timing of SST were statistically equivalent, but the decrease for Late timing of $\mathrm{H}-\mathrm{CaCl}_{2}$ was more modest. To an even greater degree than was seen under minimal and moderate drop conditions, there was a significant increase in estimated yield for every foliar Ca treatment. $\mathrm{L}-\mathrm{CaCl}_{2}$ and $\mathrm{H}-\mathrm{CaCl}_{2}$ increased yield estimate to the same extent at each timing. Only L- $\mathrm{CaCl}_{2}$ was more effective than either rate at Mid timing, which were equivalent to $\mathrm{L}-\mathrm{CaCl}_{2}$ and superior to $\mathrm{H}-\mathrm{CaCl}_{2}$ at Early timing, the latter being equivalent to both rates at Late timing. Only L-CaCl 2 had as little an effect on estimated yield as SST at Mid timing, though this treatment was still statistically different from the control. Fruit per cluster was significantly increased by all treatments except for the Late timing applications; were equivalent for the two application rates at Early, Mid, and All timings; and was statistically intermediate for SST at Mid timing, but this was equivalent to $\mathrm{L}-\mathrm{CaCl}_{2}$ at Early timing.

At the $\mathrm{H}-\mathrm{CaCl}_{2}$ rate, some phytotoxicity was observed on leaves, especially following Early and Mid applications, but there was no observable damage to either flowers or fruit. The lack of a negative effect on fruit was verified in that the reduction in fruit drop was concurrent with increased yield estimate and without negative effects on yield components such as fruit size. In fact, averaged across three sites and two years, there were no significant differences in green or ripe fruit FW between the control and any foliar $\mathrm{Ca}$ treatment. There were negative relationships between the percent fruit drop and estimated yield across treatment combinations under moderate and high severity of GFD, and there were positive relationships between fruit per cluster and estimated yield across all severities of GFD (Figure 2).

All foliar treatments resulted in significant increases in percent Ca in green fruit samples on both a FW and DW basis in 2015 (Table 4). Only the control was analyzed in 2016, making statistical comparison impossible. Statistically greater increases in green fruit $\mathrm{Ca}$ were seen for $\mathrm{H}-\mathrm{CaCl}_{2}$ compared to $\mathrm{L}-\mathrm{CaCl}_{2}$ at Mid, Late and All timings. $\mathrm{H}-\mathrm{CaCl}_{2}$ at Early timing did not differ from $\mathrm{L}-\mathrm{CaCl}_{2}$ at the same timing or SST at Mid timing. Both $\mathrm{L}-\mathrm{CaCl}_{2}$ and $\mathrm{H}-\mathrm{CaCl}_{2}$ at All timing were higher than for treatments of the same rates at any other timing, demonstrating generally greater increases in green fruit $\mathrm{Ca}$ for seven applications compared with three. 


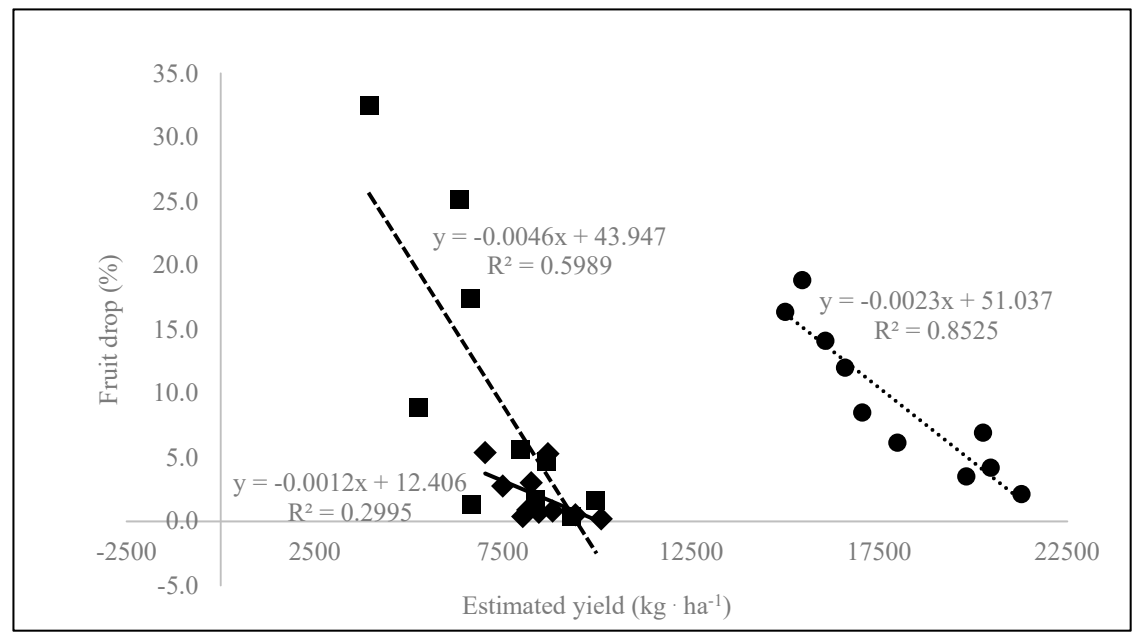

(a)

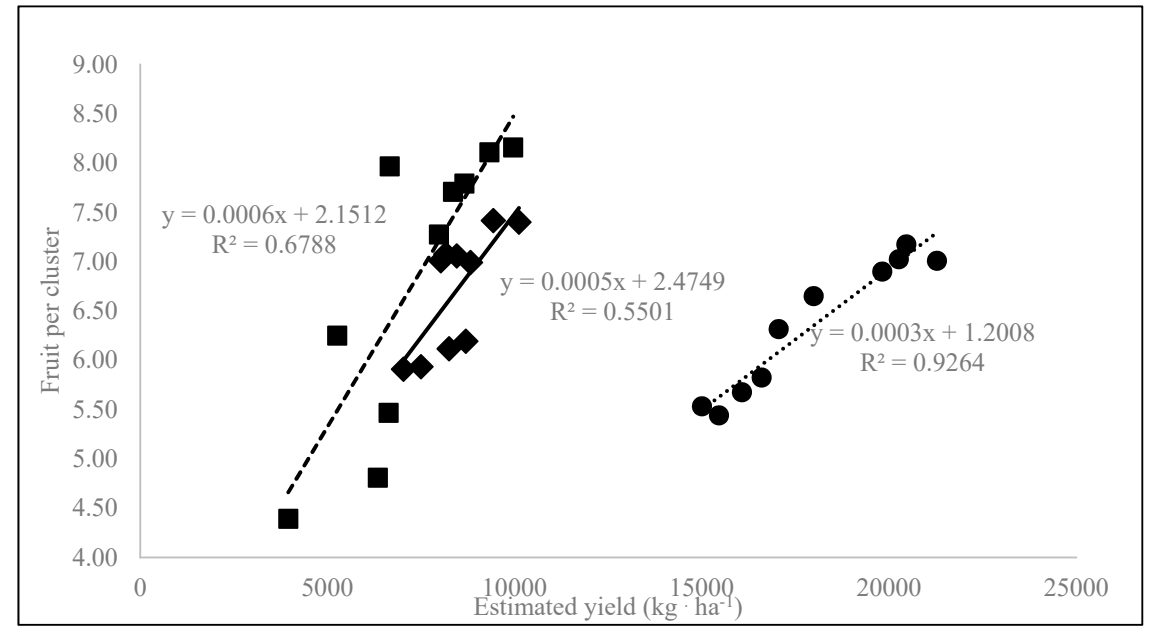

(b)

Figure 2. XY plots with regression equations and coefficients of determination between plant responses as affected by foliar Ca applications to 'Draper' highbush blueberry across three farm sites in the Fraser Valley, British Columbia, Canada in 2016 (a) Percent fruit drop versus estimated yield; (b) Fruit per cluster versus estimated yield, $\bullet=$ Site 1 (dotted line), $\mathbf{\square}=$ Site 2 (dashed line), $\bullet=$ Site 3 (solid line).

Leaf samples taken at the same time as green fruit sampling, rather than at the typical late July sampling date recommended for tissue sampling [30], also showed significant differences in Ca on both a FW and DW basis across treatments. Compared with the control in 2015, these increases were significant for $\mathrm{H}-\mathrm{CaCl}_{2}$ at the Late and All timings (on both a FW and $\mathrm{DW}$ basis) and for $\mathrm{L}-\mathrm{CaCl}_{2}$ at All timing (on only a DW basis). These findings likely relate to the proximity of application timings to sampling dates as newly developed leaves unfold rapidly during this early part of the summer and any potential increases in leaf Ca from earlier applications would have been on earlier sets of leaves than those that were sampled as the first fully unfolded leaves on new shoots.

Averaged across 2015 and 2016, ripe fruit Ca was significantly higher for virtually all foliar Ca treatments compared with the control on both a FW and DW basis (Table 5). The exceptions were L-CaCl ${ }_{2}$ at Early timing on both a FW and DW basis and SST at Mid timing on only a DW basis. No $\mathrm{L}-\mathrm{CaCl}_{2}$ treatment resulted in higher $\mathrm{Ca}$ than SST when applied the same number of times. $\mathrm{H}-\mathrm{CaCl}_{2}$ was higher than $\mathrm{L}-\mathrm{CaCl}_{2}$ for Early, Mid, and All timings but not Late timing. $\mathrm{H}-\mathrm{CaCl}_{2}$ and $\mathrm{L}-\mathrm{CaCl}_{2}$ were equivalent to one another at Mid and Late timings. In contrast $\mathrm{H}-\mathrm{CaCl}_{2}$ was higher than $\mathrm{L}-\mathrm{CaCl}_{2}$ for All timing, and the additional applications for this treatment resulted in higher Ca than any of the other timings for each of the rates. 
Late leaf samples, taken at the recommended sampling date for blueberry tissue analysis [30], showed some significant differences in Ca content across treatments when 2015 and 2016 data were averaged (Table 6). Only $\mathrm{H}-\mathrm{CaCl}_{2}$ at $\mathrm{Mid}$, Late, and All timings were significantly increased over the control on both a FW and DW basis, but there were no significant differences between these combinations of Ca rates and timings. Mid timing of SST and Early timing of both $\mathrm{H}-\mathrm{CaCl}_{2}$ or L-CaCl had statistically equivalent leaf Ca content. Comparing the average treatment values for each of the three locations $(n=10)$, there were negative relationships between percent fruit drop and ripe fruit $\mathrm{Ca}$ on a FW basis that varied in strength from $R^{2}=0.2121, R^{2}=0.3188$, to $R^{2}=0.4336$ for Sites 1,2 , and 3 , respectively, in 2016 (Figure 3). Also, there were positive associations between fruit per cluster and ripe fruit Ca on a FW basis that varied in strength from $R^{2}=0.1266, R^{2}=0.3985$, to $R^{2}=0.3055$ for Sites 1,2 , and 3, respectively.

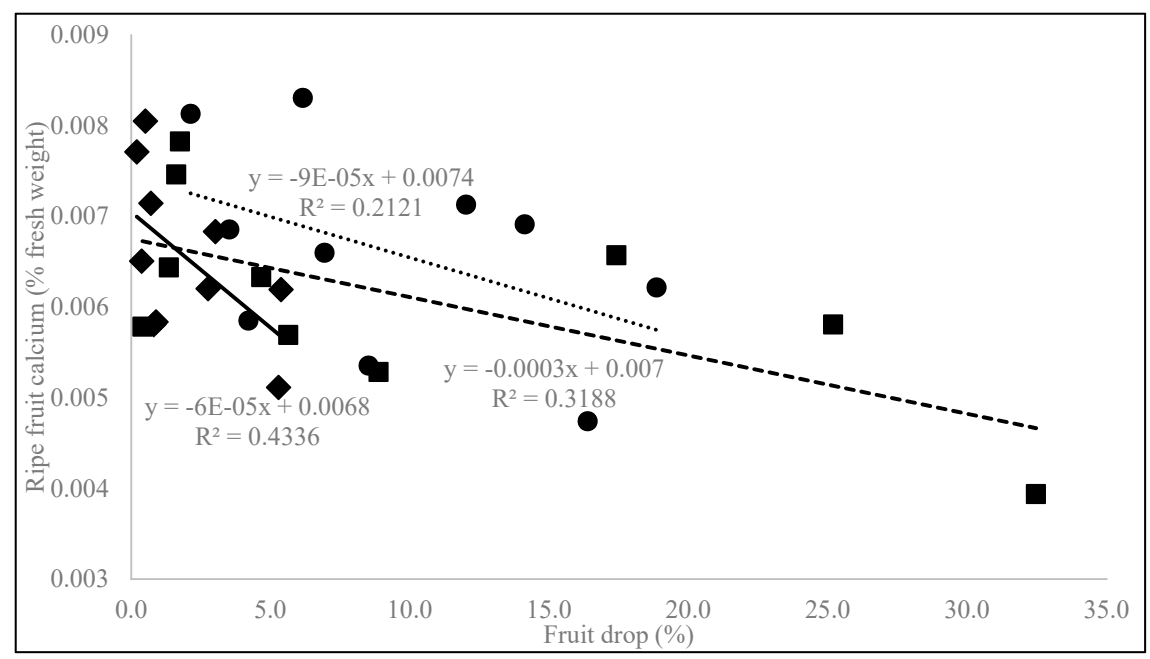

(a)

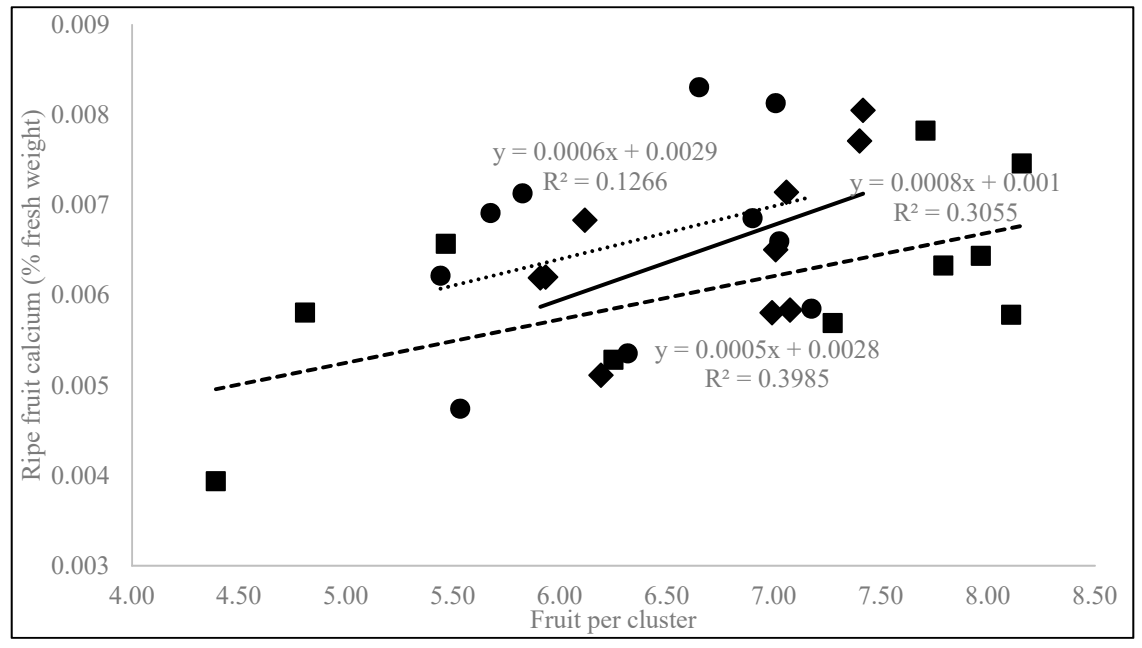

(b)

Figure 3. $\mathrm{XY}$ plots with regression equations and coefficients of determination between plant responses and fruit Ca concentration as affected by foliar Ca applications to 'Draper' highbush blueberry across three farm sites in the Fraser Valley, British Columbia, Canada in 2016 (a) Percent fruit drop versus ripe fruit calcium; (b) Fruit per cluster versus ripe fruit calcium, $\bullet=$ Site 1 (dotted line), $\mathbf{\square}=$ Site 2 (dashed line), $\bullet$ Site 3 (solid line). 
Table 4. Mean \pm SE green fruit and early leaf calcium concentrations in 'Draper' highbush blueberry in response to foliar Ca products, application timings and rates across three sites in the Fraser Valley, British Columbia, Canada in 2015 as well as for control plots in 2016.

\begin{tabular}{|c|c|c|c|c|c|c|c|}
\hline \multirow[b]{2}{*}{ Year } & \multirow[b]{2}{*}{ Product } & \multirow[b]{2}{*}{ Timing } & \multirow[b]{2}{*}{ Rate (ppm) } & \multicolumn{2}{|c|}{ Green Fruit Calcium $(\%)^{7}$} & \multicolumn{2}{|c|}{ Early Leaf Calcium (\%) } \\
\hline & & & & Dry Weight & Fresh Weight & Dry Weight & Fresh Weight \\
\hline \multirow{5}{*}{2015} & SST $^{1}$ & Mid & 800 & $0.12 \pm 0.01 \mathrm{~b}$ & $0.015 \pm 0.001 b$ & $0.66 \pm 0.05 a-c$ & $0.122 \pm 0.009 \mathrm{ab}$ \\
\hline & \multirow{4}{*}{$\mathrm{CaCl}_{2}{ }^{2}$} & Early $^{3}$ & $\begin{array}{l}1360 \\
2720\end{array}$ & $\begin{array}{l}0.12 \pm 0.01 b \\
0.12 \pm 0.01 b\end{array}$ & $\begin{array}{l}0.015 \pm 0.001 b \\
0.015 \pm 0.001 b\end{array}$ & $\begin{array}{c}0.65 \pm 0.05 \mathrm{ab} \\
0.63 \pm 0.05 \mathrm{a}\end{array}$ & $\begin{array}{l}0.120 \pm 0.008 a \\
0.116 \pm 0.009 a\end{array}$ \\
\hline & & $\operatorname{Mid}^{4}$ & $\begin{array}{l}1360 \\
2720\end{array}$ & $\begin{array}{l}0.12 \pm 0.01 b \\
0.14 \pm 0.01 c\end{array}$ & $\begin{array}{l}0.015 \pm 0.001 b \\
0.017 \pm 0.001 c\end{array}$ & $\begin{array}{c}0.64 \pm 0.05 a b \\
0.67 \pm 0.05 a-c\end{array}$ & $\begin{array}{c}0.118 \pm 0.009 a \\
0.123 \pm 0.008 a-c\end{array}$ \\
\hline & & Late $^{5}$ & $\begin{array}{l}1360 \\
2720\end{array}$ & $\begin{array}{l}0.12 \pm 0.01 b \\
0.14 \pm 0.01 c\end{array}$ & $\begin{array}{l}0.016 \pm 0.001 b \\
0.019 \pm 0.001 c\end{array}$ & $\begin{array}{l}0.66 \pm 0.04 \mathrm{ab} \\
0.72 \pm 0.06 \mathrm{~cd}\end{array}$ & $\begin{array}{c}0.120 \pm 0.008 \mathrm{a} \\
0.133 \pm 0.011 b c\end{array}$ \\
\hline & & All ${ }^{6}$ & $\begin{array}{l}1360 \\
2720\end{array}$ & $\begin{array}{l}0.14 \pm 0.00 \mathrm{c} \\
0.19 \pm 0.01 \mathrm{~d}\end{array}$ & $\begin{array}{l}0.018 \pm 0.001 c \\
0.023 \pm 0.001 d\end{array}$ & $\begin{array}{c}0.69 \pm 0.06 \mathrm{~b}-\mathrm{d} \\
0.75 \pm 0.06 \mathrm{~d}\end{array}$ & $\begin{array}{c}0.125 \pm 0.010 a-c \\
0.134 \pm 0.008 c\end{array}$ \\
\hline $\begin{array}{c}2016^{8} \\
\text { Average }^{8}\end{array}$ & Control & $\mathrm{n} / \mathrm{a}$ & 0 & $\begin{array}{c}0.11 \pm 0.01 \mathrm{a} \\
0.12 \pm 0.00 \\
0.11 \pm 0.01\end{array}$ & $\begin{array}{c}0.014 \pm 0.001 \mathrm{a} \\
0.017 \pm 0.001 \\
0.015 \pm 0.001\end{array}$ & $\begin{array}{c}0.63 \pm 0.05 a \\
0.57 \pm 0.03 \\
0.60 \pm 0.04\end{array}$ & $\begin{array}{c}0.116 \pm 0.008 \mathrm{a} \\
0.214 \pm 0.010 \\
0.165 \pm 0.009\end{array}$ \\
\hline
\end{tabular}

${ }^{1}$ Signature ${ }^{\circledR} 8 \%$ Calcium Silicate. ${ }^{2}$ TETRA Flake $77 \%$ calcium chloride. ${ }^{3}$ Three weekly early applications starting at mid-bloom stage. ${ }^{4}$ Three weekly middle applications starting at end of petal fall stage. ${ }^{5}$ Three weekly late applications starting during early green fruit stage. ${ }^{6}$ Seven weekly applications spanning mid-bloom to green fruit stages. ${ }^{7}$ Treatment combinations not connected by the same letter are statistically different $(p<0.05)$ based on linear contrasts extracted from mixed regression models. ${ }^{8}$ No statistical comparisons possible as analysis only conducted for control in 2016 
Table 5. Mean \pm SE ripe fruit calcium concentration on a dry and fresh weight basis in 'Draper' highbush blueberry in response to foliar Ca products, application timings and rates across three sites in the Fraser Valley, British Columbia, Canada in 2015 and 2016.

\begin{tabular}{|c|c|c|c|c|c|c|c|c|}
\hline \multirow[b]{2}{*}{ Product } & \multirow[b]{2}{*}{ Timing } & \multirow[b]{2}{*}{ Rate (ppm) } & \multicolumn{3}{|c|}{ Ripe Fruit Ca (\% dry Weight) ${ }^{7}$} & \multicolumn{3}{|c|}{ Ripe Fruit Ca (\% Fresh Weight) } \\
\hline & & & 2015 & 2016 & Average & 2015 & 2016 & Average \\
\hline SST $^{1}$ & Mid & 800 & $0.04 \pm 0.00 \mathrm{ab}$ & $0.04 \pm 0.00 \mathrm{bc}$ & $0.04 \pm 0.00 \mathrm{ab}$ & $0.006 \pm 0.000 \mathrm{ab}$ & $0.007 \pm 0.000 \mathrm{c}-\mathrm{e}$ & $0.007 \pm 0.000 \mathrm{~b}$ \\
\hline \multirow{4}{*}{$\mathrm{CaCl}_{2}{ }^{2}$} & Early $^{3}$ & $\begin{array}{l}1360 \\
2720\end{array}$ & $\begin{array}{c}0.04 \pm 0.00 a \\
0.04 \pm 0.00 a-c\end{array}$ & $\begin{array}{l}0.04 \pm 0.00 \mathrm{ab} \\
0.05 \pm 0.00 \mathrm{~cd}\end{array}$ & $\begin{array}{c}0.04 \pm 0.00 \mathrm{a} \\
0.04 \pm 0.00 \mathrm{bc}\end{array}$ & $\begin{array}{c}0.006 \pm 0.000 \mathrm{a} \\
0.007 \pm 0.000 \mathrm{a}-\mathrm{c}\end{array}$ & $\begin{array}{c}0.005 \pm 0.001 \mathrm{a} \\
0.007 \pm 0.001 \mathrm{c}-\mathrm{f}\end{array}$ & $\begin{array}{c}0.006 \pm 0.000 \mathrm{a} \\
0.007 \pm 0.000 \mathrm{bc}\end{array}$ \\
\hline & $\operatorname{Mid}^{4}$ & $\begin{array}{l}1360 \\
2720\end{array}$ & $\begin{array}{c}0.04 \pm 0.00 \mathrm{bc} \\
0.05 \pm 0.00 \mathrm{~d}\end{array}$ & $\begin{array}{l}0.04 \pm 0.00 \mathrm{a}-\mathrm{c} \\
0.05 \pm 0.00 \mathrm{c}-\mathrm{e}\end{array}$ & $\begin{array}{c}0.04 \pm 0.00 \mathrm{bc} \\
0.05 \pm 0.00 \mathrm{~d}\end{array}$ & $\begin{array}{c}0.007 \pm 0.001 \mathrm{a}-\mathrm{c} \\
0.008 \pm 0.000 \mathrm{c}\end{array}$ & $\begin{array}{l}0.006 \pm 0.000 \mathrm{a}-\mathrm{c} \\
0.007 \pm 0.000 \mathrm{~d}-\mathrm{f}\end{array}$ & $\begin{array}{l}0.007 \pm 0.000 b \\
0.008 \pm 0.000 c\end{array}$ \\
\hline & Late $^{5}$ & $\begin{array}{l}1360 \\
2720\end{array}$ & $\begin{array}{c}0.04 \pm 0.00 \mathrm{~b}-\mathrm{d} \\
0.05 \pm 0.00 \mathrm{~cd}\end{array}$ & $\begin{array}{l}0.04 \pm 0.00 \mathrm{bc} \\
0.05 \pm 0.00 \mathrm{~cd}\end{array}$ & $\begin{array}{l}0.04 \pm 0.00 \mathrm{bc} \\
0.05 \pm 0.00 \mathrm{~cd}\end{array}$ & $\begin{array}{c}0.007 \pm 0.000 \mathrm{bc} \\
0.007 \pm 0.000 \mathrm{c}\end{array}$ & $\begin{array}{l}0.007 \pm 0.000 b-d \\
0.007 \pm 0.000 c-e\end{array}$ & $\begin{array}{l}0.007 \pm 0.000 \mathrm{bc} \\
0.007 \pm 0.000 \mathrm{bc}\end{array}$ \\
\hline & All ${ }^{6}$ & $\begin{array}{l}1360 \\
2720\end{array}$ & $\begin{array}{c}0.04 \pm 0.00 \mathrm{~cd} \\
0.06 \pm 0.00 \mathrm{e}\end{array}$ & $\begin{array}{c}0.05 \pm 0.00 \mathrm{de} \\
0.05 \pm 0.00 \mathrm{e}\end{array}$ & $\begin{array}{l}0.05 \pm 0.00 \mathrm{~d} \\
0.06 \pm 0.00 \mathrm{e}\end{array}$ & $\begin{array}{c}0.007 \pm 0.000 \mathrm{bc} \\
0.009 \pm 0.000 \mathrm{~d}\end{array}$ & $\begin{array}{c}0.008 \pm 0.000 \mathrm{ef} \\
0.008 \pm 0.000 \mathrm{f}\end{array}$ & $\begin{array}{l}0.007 \pm 0.000 c \\
0.009 \pm 0.000 d\end{array}$ \\
\hline Control & $\mathrm{n} / \mathrm{a}$ & 0 & $0.04 \pm 0.00 \mathrm{ab}$ & $0.04 \pm 0.00 \mathrm{a}$ & $0.04 \pm 0.00 \mathrm{a}$ & $0.006 \pm 0.000 \mathrm{a}$ & $0.006 \pm 0.000 \mathrm{ab}$ & $0.006 \pm 0.000 \mathrm{a}$ \\
\hline
\end{tabular}

${ }^{1}$ Signature ${ }^{\circledR} 8 \%$ Calcium Silicate. ${ }^{2}$ TETRA Flake $77 \%$ calcium chloride. ${ }^{3}$ Three weekly early applications starting at mid-bloom stage. ${ }^{4}$ Three weekly middle applications starting at end of petal fall stage. ${ }^{5}$ Three weekly late applications starting during early green fruit stage. ${ }^{6}$ Seven weekly applications spanning mid-bloom to green fruit stages. ${ }^{7}$ Treatment combinations not connected by the same letter are statistically different $(p<0.05)$ based on linear contrasts extracted from mixed regression models. However, lack of numerical differences between significantly different values at the appropriate number of significant figures may indicate a lack of biological relevance for these differences on a dry weight basis. 
Table 6. Mean \pm SE late leaf sample concentration on a dry and fresh weight basis in 'Draper' highbush blueberry in response to foliar Ca products, application timings and rates across three sites in the Fraser Valley, British Columbia, Canada in 2015 and 2016.

\begin{tabular}{|c|c|c|c|c|c|c|c|c|}
\hline \multirow[b]{2}{*}{ Product } & \multirow[b]{2}{*}{ Timing } & \multirow[b]{2}{*}{ Rate (ppm) } & \multicolumn{3}{|c|}{ Late leaf Ca (\% Dry Weight) ${ }^{7}$} & \multicolumn{3}{|c|}{ Late Leaf Ca (\% Fresh Weight) } \\
\hline & & & 2015 & 2016 & Average & 2015 & 2016 & Average \\
\hline $\mathrm{SST}^{1}$ & Mid & 800 & $0.81 \pm 0.04 \mathrm{ab}$ & $0.85 \pm 0.03 \mathrm{ab}$ & $0.83 \pm 0.03 \mathrm{ab}$ & $0.322 \pm 0.015 \mathrm{ab}$ & $0.365 \pm 0.013 \mathrm{ab}$ & $0.344 \pm 0.011 \mathrm{a}-\mathrm{c}$ \\
\hline \multirow{4}{*}{$\mathrm{CaCl}_{2}{ }^{2}$} & Early $^{3}$ & $\begin{array}{l}1360 \\
2720\end{array}$ & $\begin{array}{l}0.81 \pm 0.04 a b \\
0.81 \pm 0.04 a b\end{array}$ & $\begin{array}{c}0.83 \pm 0.04 a \\
0.88 \pm 0.04 a-c\end{array}$ & $\begin{array}{c}0.82 \pm 0.03 a \\
0.84 \pm 0.03 a-c\end{array}$ & $\begin{array}{l}0.322 \pm 0.015 \mathrm{ab} \\
0.323 \pm 0.013 \mathrm{ab}\end{array}$ & $\begin{array}{c}0.353 \pm 0.015 a \\
0.375 \pm 0.015 a-c\end{array}$ & $\begin{array}{c}0.338 \pm 0.011 \mathrm{ab} \\
0.349 \pm 0.011 \mathrm{a}-\mathrm{d}\end{array}$ \\
\hline & $\operatorname{Mid}^{4}$ & $\begin{array}{l}1360 \\
2720\end{array}$ & $\begin{array}{l}0.80 \pm 0.05 \mathrm{ab} \\
0.81 \pm 0.04 \mathrm{ab}\end{array}$ & $\begin{array}{c}0.88 \pm 0.03 a-c \\
0.92 \pm 0.03 c\end{array}$ & $\begin{array}{c}0.84 \pm 0.03 a-c \\
0.87 \pm 0.03 b c\end{array}$ & $\begin{array}{l}0.320 \pm 0.019 \mathrm{ab} \\
0.322 \pm 0.015 \mathrm{ab}\end{array}$ & $\begin{array}{c}0.375 \pm 0.014 a-c \\
0.393 \pm 0.015 c\end{array}$ & $\begin{array}{l}0.348 \pm 0.013 \mathrm{a}-\mathrm{d} \\
0.357 \pm 0.013 \mathrm{~b}-\mathrm{d}\end{array}$ \\
\hline & Late $^{5}$ & $\begin{array}{l}1360 \\
2720\end{array}$ & $\begin{array}{l}0.82 \pm 0.04 \mathrm{ab} \\
0.84 \pm 0.03 \mathrm{bc}\end{array}$ & $\begin{array}{l}0.89 \pm 0.03 b c \\
0.90 \pm 0.03 b c\end{array}$ & $\begin{array}{c}0.85 \pm 0.03 a-c \\
0.87 \pm 0.02 b c\end{array}$ & $\begin{array}{l}0.331 \pm 0.016 \mathrm{bc} \\
0.338 \pm 0.014 \mathrm{bc}\end{array}$ & $\begin{array}{l}0.380 \pm 0.013 b c \\
0.385 \pm 0.013 b c\end{array}$ & $\begin{array}{c}0.356 \pm 0.011 \mathrm{a}-\mathrm{d} \\
0.362 \pm 0.010 \mathrm{~cd}\end{array}$ \\
\hline & All ${ }^{6}$ & $\begin{array}{l}1360 \\
2720\end{array}$ & $\begin{array}{c}0.83 \pm 0.05 \mathrm{ab} \\
0.88 \pm 0.04 \mathrm{c}\end{array}$ & $\begin{array}{l}0.89 \pm 0.03 b c \\
0.89 \pm 0.03 b c\end{array}$ & $\begin{array}{c}0.86 \pm 0.03 a-c \\
0.88 \pm 0.02 c\end{array}$ & $\begin{array}{c}0.331 \pm 0.018 b c \\
0.351 \pm 0.016 c\end{array}$ & $\begin{array}{c}0.380 \pm 0.012 b c \\
0.379 \pm 0.014 a-c\end{array}$ & $\begin{array}{c}0.355 \pm 0.012 \mathrm{a}-\mathrm{d} \\
0.365 \pm 0.011 \mathrm{~d}\end{array}$ \\
\hline Control & $\mathrm{n} / \mathrm{a}$ & 0 & $0.78 \pm 0.04 a$ & $0.85 \pm 0.03 \mathrm{ab}$ & $0.81 \pm 0.02 a$ & $0.305 \pm 0.017 \mathrm{a}$ & $0.370 \pm 0.012 \mathrm{a}-\mathrm{c}$ & $0.337 \pm 0.012 \mathrm{a}$ \\
\hline
\end{tabular}

1 Signature ${ }^{\circledR} 8 \%$ Calcium Silicate. ${ }^{2}$ TETRA Flake $77 \%$ calcium chloride. ${ }^{3}$ Three weekly early applications starting at mid-bloom stage. ${ }^{4}$ Three weekly middle applications starting at end of petal fall stage. ${ }^{5}$ Three weekly late applications starting during early green fruit stage. ${ }^{6}$ Seven weekly applications spanning mid-bloom to green fruit stages. ${ }^{7}$ Treatment combinations not connected by the same letter are statistically different $(p<0.05)$ based on linear contrasts extracted from mixed regression models. 


\section{Discussion}

\subsection{Correlation of Green Fruit Drop in 'Draper' Blueberry with Fruit Calcium and Plant Vigor}

The correlation between reduced GFD and higher fruit Ca resulting from foliar applications in the current study, relates to the physiology of plant Ca nutrition in numerous crop species. Since $\mathrm{Ca}$ has little mobility in the phloem, its movement from the root system to the above-ground parts of the plant is primarily through the xylem, driven by transpiration [34]. Compared to other cationic nutrients that can move in the phloem (e.g., $\mathrm{K}$ and Mg), Ca transport to fruit is often much lower than to leaves, resulting in deficiencies in many crops e.g., [5-7]. Environmental conditions that result in low transpiration, low uptake of $\mathrm{Ca}$ and high competition between floral and vegetative organs lead to these disorders, especially in crops with separate floral and vegetative buds as in blueberry [20]. While flowers and fruits are typically stronger sinks for phloem transported elements and carbohydrates than shoot apices, the movement of xylem transported elements is dictated by transpirative demand. A high transpiring organ (e.g., leaves with many active stomata) will draw more water from the roots than a low transpiring organ (e.g., fruit with relatively few stomata that decrease in function as the fruit develop) [34]. Competition for Ca as it moves by mass flow in the xylem is not a complete explanation of the uptake and differential allocation of this mineral because water transport to the fruit does not always correlate well with allocation of $\mathrm{Ca}$, as seen in apple [13]. However, competition with other ions such as $\mathrm{K}$ may be aggravated under low transpiration and high competition [35].

The association between severity of GFD and plant vigor evaluated in the current study through comparison of $\mathrm{Ca}$ treatment under different rates of $\mathrm{N}$ management, is in accordance with findings for Ca disorders in other crops. Specifically, several crops demonstrate an interaction between Ca disorders and $\mathrm{N}$ management, with high levels of $\mathrm{N}$ resulting in increased vigor and often triggering the Ca deficiency or exacerbating the related disorder [19]. In apple, for which these relations have been most extensively studied, the competition between vigorous shoot growth and fruit Ca was proposed more than sixty years ago [36]. This interaction is most likely due to competition between growing vegetative shoot apices and developing fruit rather than inhibition of Ca uptake from the roots by excessive $\mathrm{N}$ in the root zone [37]. Not just vigor of shoot growth but the timing of onset for vigorous growth relative to fruit development is important in some Ca disorders in other crops. Various rates and durations of Ca uptake to the fruit have been document in apple, ranging from primarily in the first part of fruit growth to occurring with a decreasing linear trend that extends until harvest $[16,38]$. In any case, Ca concentration in apple tends to reach its maximum soon after bloom before dropping due to dilution as the fruit grow through cell enlargement [39]. Therefore, the key $\mathrm{Ca}$ loading phase is early in development for many types of fruit and is highly influenced by variation in transpiration [34], but the reasons for the decline in xylem transport of Ca into fruit after this phase are still only partially understood, likely relating to a decline in xylem function [40].

\subsection{Calcium Deficiency as a Genetic Pre-Disposition to Green Fruit Drop in 'Draper' Blueberry}

The current finding that foliar Ca corrects GFD in 'Draper' builds on the current knowledge of Ca nutrition in blueberry. In Oregon, a high leaf $\mathrm{Ca}$ and low fruit $\mathrm{Ca}$ were noted in a replicated survey of tissue nutrient content across a range of cultivars [8], which validates that an interaction between $\mathrm{Ca}$ and $\mathrm{N}$ is observed and may be due to competition between these plant organs for Ca in the xylem sap. These authors explain the higher leaf $\mathrm{Ca}$ in 'Draper' as being related to the high vigor and many growing shoot tips of 'Draper' in Oregon. The severity of GFD in Southwestern BC compared with the near lack of GFD in Oregon indicates differential performance across environments. Specifically, this belies marginal adaptation of 'Draper' to Southwestern BC in comparison to a highly adaptive region like Oregon. Consequently, Ca uptake, adequacy of allocation to the fruit or both factors are in a range of marginal sufficiency in this region, entering deficiency under certain field- and season-specific conditions, subsequently resulting in GFD. 
In apple, the occurrence and severity of bitter pit is related, among many factors, to the specific cultivar and where it is grown. Pre-disposition of 'Draper' to GFD is similar, a physiological condition with an important genetic component, manifesting under certain environmental conditions. While 'Draper' is the first highbush blueberry commercial cultivar to manifest this condition, GFD has also been observed in progenies of 'Draper' in breeding plots in the Willamette Valley of Oregon (C. Finn, personal communication). As with apple bitter pit, GFD symptoms include decayed internal tissues with no visible symptoms to the exterior. The internal browning is likely related to action of degradation enzymes. Lack of damage to the exterior of the fruit is due to the ability of the soluble fraction of fruit $\mathrm{Ca}$ to move within the fruit [41], leading to deficiencies in some parts and not in others. Detailed comparison of skin, pulp and seed Ca levels have not been conducted to study a presumed gradient in fruit Ca relating to GFD in 'Draper'.

Therefore, with a genetic pre-disposition toward relatively greater allocation of Ca toward vegetative structures at the expense of reproductive structures [8], 'Draper' responds to the environmental conditions of Southwestern BC with a deficiency that can be characterized as an environmental maladaptation. With Ca deficiency as a proximate cause of GFD, interacting with plant vigor and presumably other factors, the ultimate cause of this maladaptation could be due to any number of physiological mechanisms or disfunctions, likely relating to the high leaf/fruit Ca ratio for the cultivar. For example, one could speculate that there is low expression of a cell membrane Ca pump gene under environmental conditions conducive to GFD. As contributing factors, edaphic soil properties and horticultural management practices may aggravate the effects of the climatic conditions on plant phenology that reduce Ca uptake or result in greater competition for Ca allocation to the fruit.

Temperature, light intensity, precipitation, soil moisture, and relative humidity are all important factors that affect transpiration. Climatic conditions in Southwestern BC are generally cooler, wetter and more often overcast during spring phenological development of blueberry in comparison with Oregon. In most years, Southwestern BC is likely to have higher relative humidity, wetter soils, lower light levels, and cooler temperatures, indicating generally lower transpirative demand, in comparison to Oregon with minimal GFD. High relative humidity decreases Ca uptake in either the fruit or vegetative tissues of sweet pepper (Capsicum annuum L.), tomato, and apple [6,42,43]. Further, well-watered plants have reduced transpiration, which could be made worse if leaf development is relatively delayed very early after floral bud break, as observed in the field in the case of 'Draper'. Later in the season, when fruit development is in its first stage of cell division and the shoots are in a rapid phase of elongation, excessive guttation on the leaves is sometimes observed in the field under overcast conditions with high relative humidity, indicative of positive root pressure for xylem sap. Tomato and apple demonstrate much reduced allocation of $\mathrm{Ca}$ to fruit under experimental conditions of high relative humidity [44]. From these field observations, one or both potential environmental factors could be involved in triggering GFD in 'Draper'.

Parsing the effects of these putative environmental triggers would require detailed documentation of fruit Ca loading over time and a comparative study of phenological and climatic factors across regions with and without GFD. A companion survey of tissue and soil nutrient values across BC, WA, and OR in 2015 and 2016 was conducted as a preliminary investigation of these fundamental issues (unpublished data). Nevertheless, the current explanation of GFD is consistent with what is known of Ca disorders in other fruit such as apple and pear, the severity of which tend to vary from year-to-year and site-to-site by directly impacting plant parts, indirectly interfering with the interactions between plant parts or otherwise responding to cultural management practices [20].

\subsection{Mitigation of Green Fruit Drop in 'Draper' Blueberry Using Corrective Foliar Calcium Applications}

In BC, GFD is observed in fields with a broad range of soil Ca (data not shown), with some severely affected fields having very high levels of soil Ca based on established nutrient management recommendations for the Pacific Northwest [30]. For this reason, and since blueberry is a calcifuge that is highly efficient at taking up Ca under low $\mathrm{pH}$ conditions [11], soil applications are unlikely to 
impact the incidence of GFD. Whereas application of lime or gypsum to the soil may benefit overall crop health in the long-term management of soil $\mathrm{pH}$ of blueberry plantings where $\mathrm{pH}$ is dropping below the recommended range, soil applications of these fertilizers demonstrated little effect on fruit $\mathrm{Ca}$ and no effect on fruit yield, size or firmness in studies in Michigan [45].

As seen in other crops, loading of Ca into blueberry fruit occurs primarily when shoot growth is limited, and low transpiring fruit accumulate less $\mathrm{Ca}$ than high transpiring leaves overall [18]. This results in a high DW leaf/fruit Ca ratio, which increases several-fold as the season progresses [26]. While Ca is more likely than more mobile elements to be affected by foliar application due to its immobility within the plant, affecting a substantial change in fruit $\mathrm{Ca}$ via exogenous treatment is challenging for this same reason. That is, without translocation of $\mathrm{Ca}$ from leaves to fruit by the phloem, effective correction of acute fruit deficiencies requires movement of exogenous Ca into fruit tissues, primarily through stomata, as described in apple [46]. This is problematic because fruit stomata are only functional for a short period of time during early fruit development, the waxy cuticle decreasing their functionality as it develops [47]. In apple, uptake of exogenous Ca occurs in very small in quantities $\left(<1 \mathrm{ug} \cdot \mathrm{cm}^{-2}\right)$ during foliar management of bitter pit, necessitating as many as ten or eleven applications to be even partially successful in some varieties $[38,48]$. Notwithstanding, uptake of exogenous $\mathrm{Ca}$ is known to occur by first penetrating the cuticle and then moving apoplastically through the flesh [49]. Evidence for this ability is based on Ca concentration changes within different parts of the apple fruit during maturation, and even post-harvest [50]. With the availability of the mobile, physiologically-active forms of water-soluble Ca increasing as the fruit develop [41], the small quantity of $\mathrm{Ca}$ that effectively penetrates the fruit surface can redistribute to portions of the fruit that are deficient.

In blueberry, fruit Ca levels impact fruit quality [51], but attempts to use foliar Ca to increase fruit $\mathrm{Ca}$ concentration, usually for the purpose of improving fruit quality, have been met with varying degrees of success. In one study in Michigan, a 0.08\% Ca solution was applied to 'Bluecrop', 'Blueray', and 'Ivanhoe', but fruit $\mathrm{Ca}$ and quality parameters such as firmness were not affected [28]. In comparison, Experiment 3 used $0.136 \%$ and $0.272 \% \mathrm{Ca}$, which were $1.7 \times$ and $3.4 \times$ higher, respectively, and were effective at increasing ripe fruit $\mathrm{Ca}$ significantly for all timing treatments except for $\mathrm{L}-\mathrm{CaCl}_{2}$ at Early timing (Table 5). In Chile, increases in Ca levels in fruit skin and seeds were seen at a low rate of $0.0475 \%$, but increases in fruit pulp Ca required $0.09 \%$ or $0.18 \%$ to be detected [52]. Experiment 3, which did not compare Ca concentrations in different parts of the fruit, used rates of $\mathrm{CaCl}_{2}$ that were $1.5 \times$ and $3.0 \times$ higher, respectively, than the lowest amount needed by these researchers to affect an increase in Ca content in the pulp in addition to the skin and seeds. In another Chilean study, increases in fruit Ca were achieved following two applications at $0.06 \%$ Ca but not $0.036 \%$ Ca or $0.006 \%$ Ca [26]. The rates in Experiment 3 were $2.3 \times 4.5 \times$ higher.

In contrast, work in Oregon used a range of Ca products (chloride, silicate, acetate, and chelate) with 3-5 applications from late bloom to early green fruit development (1-4 weeks before harvest) on 'Spartan', 'Draper', 'Liberty', and 'Legacy' [53]. The highest rate of $\mathrm{CaCl}_{2}$ in this study was applied at $0.09 \% \mathrm{Ca}$ in $748 \mathrm{~L}$ water. $\mathrm{Ha}^{-1}$, and the researchers saw no significant effect on fruit Ca or fruit quality. While the concentrations used for Experiment 3 were maintained as constants, the amount of spray volume applied to experimental plots varied from 371 to $914 \mathrm{~L}$ water $\cdot \mathrm{Ha}^{-1}$, depending on the field, year, and stage of plant development. Comparing the total amount of $\mathrm{Ca}$ applied would require a nuanced comparison of the plant sizes used in these studies, but with applications being made in the current study to the point of runoff, it is the actual concentration of the spray solution that contacts the fruit surfaces that is most relevant to uptake. Therefore, the concentrations applied in the current study were $1.5 \times$ and $3.0 \times$ higher than the highest rate applied in Oregon, which largely explains the difference in results. Further, while the timings of application in Oregon started at approximately the same time as the effective Mid timing used in BC, the Oregon study did not use a surfactant, based on supplier recommendations (B. Strik, personal communication), which may also have resulted in lower uptake of Ca across fruit tissues. 
Foliar Ca treatment has long been used as a standard production practice by apple growers to decrease bitter pit [54]. Foliar applications are effective in reducing bitter pit, and this is often associated with a measurable increase in fruit Ca but not in all studies [55,56]. Determining significant differences in fruit $\mathrm{Ca}$ is often problematic in experimental bitter pit research due to a high degree of between-plant and within-plant variation in mean Ca [57,58]. Fruit Ca was determined in the current study on both a FW and DW basis to remove the impact of differences in fruit size across samples based on the same approach taken in apple research [59]. However, the results on a FW and DW basis showed very similar effects across treatments in the current study.

As seen in bitter pit control [59], $\mathrm{CaCl}_{2}$ applications demonstrated risk of phytotoxicity (i.e., leaf marginal necrosis) in blueberry when applied at the higher rate in the current study. More phytotoxicity is seen in apple in response to early applications [60], which was also observed in the current study. In Michigan, a very low rate $(0.08 \% \mathrm{Ca})$ resulted in similar phytotoxicity [28], but no such damage was observed at more than twice this rate $(0.18 \% \mathrm{Ca})$ in Chile [52], a rate that was intermediate to the low and high rates used in Experiment 3.

In summary, foliar application at sufficiently early stages of fruit development is important but so is use of the correct material. Likewise, early applications are most effective for bitter pit control in apple [59] and $\mathrm{CaCl}_{2}$ is generally the most effective material [60]. Moreover, the amount of exogenous Ca uptake by fruit is not just related to the permeability of the fruit tissues at the time of application but to the quantity of spray volume that contacts the fruit tissues and its concentration at the time of contact [61]. For these reasons, the success of the current study in increasing fruit $\mathrm{Ca}$ and mitigating GFD in 'Draper' is attributed to five factors: (1) use of a Ca material that has been demonstrated to affect high uptake in other crops; (2) use of high concentrations of $\mathrm{Ca}$, afforded by the use of a basic fertilizer product $\left(\mathrm{CaCl}_{2}\right)$ rather than a formulated product with a restricted label rate; (3) application during early stages of fruit development when stomata are most functional and the cuticle least developed; (4) repeated application, three being substantially as effective as seven; and (5) use of a surfactant in tank mixes to decrease the surface tension of water droplets as they contacted fruit tissue, extending the period of time over which Ca was absorbed. Further qualification of this final point is that applications were made to the point of run-off under slow drying conditions that were conducive to optimal foliar uptake.

\subsection{Future Research Directions for Green Fruit Drop in Blueberry}

For decades, the research in apple and tomato have indicated that low Ca predisposes these crops to bitter pit and blossom-end rot, respectively, but that there are other factors which require consideration [62,63]. While mitigation of GFD with foliar Ca applications is highly effective and straight-forward, investigation into additional factors contributing to GFD in 'Draper' highbush blueberry should be part of an integrated approach to combatting this economically devastating disorder for commercial growers. Specifically, the antagonistic relationships of Ca with $\mathrm{K}$ and $\mathrm{Mg}$ seen in apple bitter pit and strawberry tip burn, respectively, are due to the ability of these other cations to move freely via the phloem and compete with $\mathrm{Ca}$, influencing allocation to different organs $[14,64]$. Moreover, in apple, the role of $\mathrm{K}, \mathrm{Mg}, \mathrm{Zn}$, and $\mathrm{Mn}$, and ratios between these cations and $\mathrm{Ca}$, have been known for more than two decades though their role is still not fully understood [65].

Climatic maladaption resulting in poor carbohydrate partitioning is also a potential area of future research relating to the underlying physiological cause of GFD in 'Draper'. Unbalance partitioning plays a role in poor Ca allocation and contributes to bitter pit in apple [66]. In 'Draper', shade studies have not, however, demonstrated a significant effect on severity of GFD [67]. Alternatively, the use of plant growth regulators (PGRs) to modify the uptake of $\mathrm{Ca}$, or enhance its allocation to fruit, is established as strategy for decreasing bitter pit in apple. For example, PGRs such as Prohexadion-Calcium (a gibberellic acid inhibitor), 1-methylcyclopropene (1-MCP), or diphenylamine (DPA) have been used in apple $[68,69]$. The potential negative effect of the types of PGRs on fruit set make this avenue of investigation problematic. 
Seeds are important for the accumulation of fruit Ca [70], and 'Draper' does demonstrate problematic pollination under some conditions, perhaps related to a squat floral morphology or some other cause of low attractiveness to honey bees (Apis mellifera L.) [67]. However, dissection of fruit during extensive field observations across the region has demonstrated that dropped fruit consistently contain numerous developing seeds, and the pattern of GFD severity across fields and years does not present as being related to poor pollination or low fruit set. Consequently, the role of enhanced pollination as an additional GFD mitigation strategy is unlikely to be worthwhile.

In apple, $\mathrm{Ca}$ is remobilized in the xylem sap from storage in tissues such as bark prior to significant root growth [35]. The same is seen in blueberry, and it is possible that Ca levels in these storage structures is low for 'Draper' in BC. Fall foliar Ca applications to increase the amount that is stored by the plant during the dormant season, and that will be available for remobilization in the spring, is a potential strategy for reducing GFD pre-disposition. Thus far, our initial attempts to reduce GFD by increasing plant $\mathrm{Ca}$ through fall foliar applications in the previous year have not been effective (data not shown), and a subsequent study by researchers in northwestern WA has shown no effect of fall Ca on GFD in the following year [71].

Finally, the genetics of predisposition to GFD is the most important avenue of future research because the disorder is not just a feature of 'Draper'. It appears to be a heritable condition in highbush blueberry. 'Draper' is being used in many northern highbush breeding programs around the world due to its ability to transmit high fruit quality to its progeny. A few cultivars with 'Draper' as a parent (e.g., 'Calypso') have already been commercialized and are being widely planted in regions where GFD is observed. Therefore, evaluating the genetic tendency for GFD is an important objective for breeding new cultivars of blueberry.

\section{Conclusions}

The principal findings of this study are that GFD is a genetic disorder seen in 'Draper' highbush blueberry that is: (1) correlated with low fruit $\mathrm{Ca}$ and high plant vigor; and (2) corrected via foliar applications of $\mathrm{Ca}$, which: (a) require specific rates and timings to be effective; (b) result in increased yield components; and (c) correlate with higher fruit $\mathrm{Ca}$. Successful mitigation of GFD requires a $\mathrm{Ca}$ product that is readily absorbed by plant tissues, and applications should be made at relatively high concentrations compared to rates used in other studies on blueberry but ranging from approximately 75 to $150 \%$ of the rates typically used in treatment of bitter pit in apple. Leaf phytotoxicity was observed at the higher rate used in the current study, but the lower rate was as effective in reducing GFD in most cases. Three applications starting at mid-bloom were effective, as were three applications starting at the end of bloom, but commercial growers may choose to make applications across the range of these effective dates or apply more frequently than every seven days to ensure maximal $\mathrm{Ca}$ uptake. Application during slow evaporative conditions increases Ca uptake, and caution with Ca materials and rates must be taken to avoid phytotoxicity.

Author Contributions: For this study, all three authors were involved in designing the experiments, interpreting their results and producing this manuscript. Further, M.S. assisted E.M.G. in application for funding and collection of field data while C.M. assisted E.M.G. in coordination and implementation of field trials. E.M.G. performed the statistical analysis and drafted this manuscript, and C.M. and M.S. provided insight into discussion of results during manuscript preparation and revision.

Funding: This research was funded by the British Columbia Blueberry Council, Sidhu Growers Ltd., the Lower Mainland Horticultural Improvement Association, the Investment Agriculture Foundation of British Columbia grant number INN208, and Agriculture and Agri-Food Canada's Growing Forward II initiative grant number AIP-P002.

Acknowledgments: The authors thank Rudy Janzen, Rajinder and Harinder Cheema and Ajit and Paul Sanga for hosting trial sites as well as Michael Dossett, Lisa DeVetter, Bernadine Strik, Tom Baumann, and Karina Sakalauskas for providing advice during the course of this study. The authors also thank Brookside Laboratories Inc. for performing all chemical nutrient analyses for this study.

Conflicts of Interest: The authors declare no conflict of interest. 


\section{References}

1. Hancock, J.F. Blueberry Plant Denominated ‘Draper'. U.S. Plant Patent PP15,103 P2, 24 August 2004.

2. Gerbrandt, E.; Baumann, T. Cultural Innovations for New Blueberry Cultivars to Overcome Developing Challenges; Final Report to Investment Agriculture Foundation; Investment Agriculture Foundation: Victoria, BC, Canada, 2013; pp. 1-38.

3. British Columbia Ministry of Agriculture. Berry Production Guide for Commercial Growers; BC Ministry of Agriculture: Victoria, BC, Canada, 2013.

4. Gerbrandt, E. What Causes Green Fruit Drop and Can We Prevent It? In Proceedings of the 57th Annual Grower Short Course; Lower Mainland Horticultural Improvement Association: Abbotsford, BC, Canada, 2015.

5. Armstrong, M.J.; Kirkby, E.A. The influence of humidity on the mineral composition of tomato plants with special reference to calcium distribution. Plant Soil 1979, 52, 427-435. [CrossRef]

6. Choi, J.H.; Chung, G.C.; Suh, S.R. Effect of night humidity on the vegetative growth and mineral composition of tomato and strawberry plants. Sci. Hortic. 1997, 70, 293-299. [CrossRef]

7. Lötze, E.; Joubert, J.; Theron, K.I. Evaluating pre-harvest foliar calcium applications to increase fruit calcium and reduce bitter pit in 'Golden Delicious' apples. Sci. Hortic. 2008, 116, 299-304. [CrossRef]

8. Strik, B.C.; Vance, A.J. Seasonal variation in leaf nutrient concentration of northern highbush blueberry cultivars grown in conventional and organic production systems. HortScience 2015, 50, 1453-1466. [CrossRef]

9. Taiz, L.; Zeiger, E. Plant Physiology, 5th ed.; Sinauer Associates, Inc.: Sunderland, MA, USA, 2010; ISBN 978-0878938667.

10. McLaughlin, S.B.; Wimmer, R. Calcium physiology and terrestrial ecosystem processes. New Phytol. 1999, 142, 373-417. [CrossRef]

11. Hanson, E.J.; Hancock, J.F. Managing the Nutrition of Highbush Blueberries; Bulletin E-2011; Michigan State University Extension: East Lansing, MI, USA, 1996.

12. Clarkson, D.T. Roots and the delivery of solutes to the xylem. Philos. Trans. R. Soc. Ser. B 1993, 341, 5-17.

13. Atkinson, C.J.; Ruiz, L.P.; Mansfield, T.A. Calcium in the xylem sap and the regulation of its delivery to the shoot. J. Exp. Bot. 1992, 42, 1315-1324. [CrossRef]

14. Guttridge, C.G.; Bradfield, E.G.; Holder, R. Dependence of calcium transport into strawberry leaves on positive pressure in the xylem. Ann. Bot. 1981, 48, 473-480. [CrossRef]

15. Takeda, F.; Wisniewski, M.E.; Glenn, D.M. Occlusion of water pores prevents guttation in older strawberry leaves. J. Am. Soc. Hortic. Sci. 1991, 116, 1122-1125. [CrossRef]

16. Faust, M. Physiology of Temperate Zone Fruit Trees; John Wiley and Sons: New York, NY, USA, 1989.

17. Creasy, G.L.; Price, S.F.; Lombard, P.B. Evidence for xylem discontinuity in Pinot noir and Merlot grapes: Dye uptake and mineral composition during berry maturation. Am. J. Enol. Vitic. 1993, 44, 187-192.

18. White, P.J.; Broadly, M.R. Calcium in plants. Ann. Bot. 2003, 92, 487-511. [CrossRef]

19. Hirschi, K.D. The calcium conundrum. Both versatile nutrient and specific signal. Am. Soc. Plant Biol. 2004, 136, 2438-2442. [CrossRef] [PubMed]

20. Saure, M.C. Calcium translocation to flesh fruit: Its mechanism and endogenous control. Sci. Hortic. 2005, 105, 65-89. [CrossRef]

21. Abbasi, N.A.; Zafar, L.; Khan, H.A.; Qureshi, A.A. Effects of naphthalene acetic acid and calcium chloride application on nutrient uptake, growth, yield and post-harvest performance of tomato fruit. Pak. J. Bot. 2013, 45, 1581-1587.

22. Kessler, B.; Moscicki, Z.W. Effect of triiodobenzoic acid and maleic hydrazide upon the transport of foliar applied calcium and iron. Plant Publ. Agric. Res. Stn. 1957, 210-D, 70-72. [CrossRef]

23. Schupp, J.R.; Greene, D.W. Effect of aminothoxyvinylglycine (AVG) on preharvest drop, fruit quality, and maturation of 'McIntosh' apples. I. concentration and timing of dilute applications of AVG. HortScience 2004, 39, 1030-1035. [CrossRef]

24. Chen, Y.; Smagula, J.M.; Litten, W.; Dunham, S. Effect of boron and calcium foliar sprays on pollen germination and development, fruit set, seed development, and berry yield and quality in lowbush blueberry (Vaccinium angustifolium Ait.). J. Am. Soc. Hortic. Sci. 1998, 123, 524-531. [CrossRef]

25. Ochmian, I. The impact of foliar application of calcium fertilizers on the quality of highbush blueberry fruits belonging to the 'Duke' cultivar. Not. Bot. Hortic. Agrobot. 2012, 40, 163-169. [CrossRef] 
26. Stückrath, R.; Quevedo, R.; de la Fuente, L.; Hernandes, A.; Sepúlveda, V. Effect of foliar applications of calcium on the quality of blueberry fruits. J. Plant Nutr. 2008, 31, 1299-1312. [CrossRef]

27. Angeletti, P.; Castagnasso, H.; Miceli, E.; Terminiello, L.; Concellón, A.; Chaves, A.; Vicente, A.R. Effect of preharvest calcium applications on postharvest quality, softening and cell wall degradation of two blueberry (Vaccinium corymbosum) varieties. Postharvest Biol. Technol. 2010, 58, 98-103. [CrossRef]

28. Hanson, E.J. Preharvest calcium sprays do not improve highbush blueberry (Vaccinium corymbosum L.) quality. HortScience 1995, 30, 977-978. [CrossRef]

29. Kelley, C.C.; Spilsbury, R.H. Soil Survey of the Lower Fraser Valley; Publication 650, Technical Bulletin 20; Dominion of Canada, Department of Agriculture: Ottawa, ON, Canada, 1939.

30. Hart, J.; Strik, B.; White, L.; Yang, W. Nutrient Management for Blueberries in Oregon; Oregon State University Extension Service Publications: Corvallis, OR, USA, 2006; EM 8918.

31. R Development Core Team. R: A Language and Environment for Statistical Computing; R Foundation for Statistical Computing: Vienna, Austria, 2010; ISBN 3-900051-07-0. Available online: http:/ /www.R-project. org (accessed on 10 September 2010).

32. Bates, D.; Maechler, M.; Bolker, B.; Walker, S. Fitting linear mixed-effects models using lme4. J. Stat. Softw. 2015, 67, 1-48. [CrossRef]

33. Graves, S.; Piepho, H.-P.; Selzer, L.; Dorai-Raj, S. mult-compView: Visualizations of Paired Comparisons. Available online: https: / /CRAN.R-project.org / package=multcompView (accessed on 3 January 2015).

34. Marschner, H. Mineral Nutrition of Higher Plants, 2nd ed.; Academic Press: Amsterdam, The Netherlands, 1995.

35. Tromp, J. The intact curve for calcium into apple fruits under various environmental conditions. Commun. Soil Sci. Plant Anal. 1979, 10, 325-335. [CrossRef]

36. Garmin, P.; Mathis, W.T. Studies of mineral balance as related to the occurrence of Baldwin spot in Connecticut. Bull. Conn. Agric. Exp. Stat. 1956, 601, 1-19.

37. Kramer, P.J.; Bullock, H.C. Seasonal variations in the proportions of suberized and unsuberized roots of trees in relation to the absorption of water. Am. J. Bot. 1966, 53, 200-204. [CrossRef]

38. Zavalloni, C.; Marangoni, B.; Scudellari, D. Dynamics of uptake of calcium, potassium and magnesium into apple fruit in a high density planting. Acta Hortic. 2001, 564, 113-121. [CrossRef]

39. Quinlan, J.D. Chemical composition of developing and shed fruits of Laxton's Fortune apple. J. Hortic. Sci. 1969, 44, 97-106. [CrossRef]

40. Dražeta, L.; Lang, A.; Morgan, L.; Volz, R.; Jameson, P.E. Bitter pit and vascular function in apples. Acta Hortic. 2001, 564, 387-392. [CrossRef]

41. Himelrick, D.G.; Walker, C.E. Seasonal trends in calcium, magnesium, and potassium fractions in apple leaf and fruit tissues. J. Am. Soc. Hortic. Sci. 1982, 107, 1078-1080.

42. Tadesse, T.; Nichols, M.A.; Hewett, E.W.; Fischer, K.J. Relative humidity around the fruit influences the mineral composition and incidence of blossom-end rot in sweet pepper fruit. J. Hortic. Sci. Biotechnol. 2001, 76, 9-16. [CrossRef]

43. Tromp, J.; van Vurre, J. Accumulation of calcium, potassium and magnesium in apple fruits under various conditions of humidity. Physiol. Plant. 1993, 27, 253-258. [CrossRef]

44. Tromp, J.; Oele, J. Shoot growth and mineral composition of leaves and fruits of apple as affected by relative humidity. Physiol. Plant. 1972, 27, 253-335. [CrossRef]

45. Hanson, E.J.; Berkheimer, S.F. Effect of soil calcium applications on blueberry yield and quality. Small Fruits Rev. 2004, 3, 133-139. [CrossRef]

46. Glenn, G.M.; Poovaiah, B.W. Cuticular permeability to calcium compounds in 'Golden Delicious' apple fruit. J. Am. Soc. Hortic. Sci. 1985, 116, 807-812.

47. Lara, I.; Belge, B.; Goulao, L.F. The fruit cuticle as a modulator of postharvest quality. Postharvest Biol. Technol. 2014, 87, 103-112. [CrossRef]

48. Ferguson, I.B.; Watkins, C.B. Bitter pit in apple fruit. Hortic. Rev. 1989, 11, 289-355.

49. Harker, F.R.; Ferguson, I.B.; Dromogoole, F.I. Calcium ion transport through tissue disks of the corticle flesh of apple fruit. Physiol. Plant. 1989, 74, 688-694. [CrossRef]

50. Perring, M.A. Redistribution of minerals in apple fruit during storage: Preliminary investigations with the variety Spartan. J. Sci. Food Agric. 1984, 35, 182-190. [CrossRef]

51. Hanson, E.J.; Beggs, J.L.; Beaudry, R.M. Applying calcium chloride postharvest to improve highbush blueberry firmness. HortScience 1993, 28, 1033-1034. [CrossRef] 
52. Retamales, J.B.; Arredondo, G. Calcio en arándano. In Caclio en Fruticultura; Yuri, J.A., Retamales, J.B., Eds.; Universidad de Talca, Escuela de Agronomía: Talca, Chile, 1995.

53. Vance, A.J.; Jones, P.; Strik, B.C. Foliar calcium applications do not improve quality or shelf life of strawberry, raspberry, blackberry, or blueberry fruit. HortScience 2017, 52, 382-387. [CrossRef]

54. Hewett, E.W.; Watkins, C.B. Bitter pit control by sprays and vacuum infiltration of Calcium in Cox's orange Pippen apples. HortScience 1991, 26, 284-286. [CrossRef]

55. Perring, M.A.; Wilkinson, B.G. The mineral composition of apples. IV. The radial distribution of chemical constituents in apples, and its significance in sampling for analysis. Commun. Soil Sci. Plant Anal. 1965, 16, 535-541. [CrossRef]

56. Porro, D.; Ceschini, A.; Pantezzi, T. The importance of advisory service in predicting bitter pit using early-season fruit analysis. Acta Hortic. 2006, 721, 273-277. [CrossRef]

57. Perring, M.A.; Jackson, C.H. The mineral composition of apples: Calcium concentration and bitter pit in relation to mean mass per apple. J. Sci. Food Agric. 1975, 26, 1493-1502. [CrossRef]

58. Turner, N.A.; Ferguson, I.B.; Sharples, R.O. Sampling and analysis for determining relationships of calcium concentration to bitter pit in apple fruit. N. Z. J. Agric. Res. 1977, 20, 525-532. [CrossRef]

59. Peryea, F.J.; Neilsen, G.H.; Faubion, D. Start-timing for calcium chloride spray programs influences fruit calcium and bitter pit in 'Braeburn' and 'Honeycrisp' apples. J. Plant Nutr. 2007, 30, 1213-1227. [CrossRef]

60. Raese, J.T.; Drake, S.R. Effect of calcium spray materials, rate, time of spray application, and rootstocks on fruit quality of 'Red' and 'Golden Delicious' apples. J. Plant Nutr. 2000, 23, 1435-1447. [CrossRef]

61. Schlegel, T.K.; Schönherr, J. Penetration of calcium chloride into apple fruits as affected by stage of fruit development. Acta Hortic. 2002, 594, 421-425. [CrossRef]

62. Stahly, E.A.; Benson, N.R. Calcium levels of 'Golden Delicious' apples sprayed with 2,3,5-triiodobenzoic acid. J. Am. Soc. Hortic. Sci. 1976, 95, 726-727.

63. Chiu, T.F.; Bould, C. Effects of shortage of calcium and other cations on 45Ca mobility, growth and nutritional disorders of tomato plants (Lycopersicon esculentum). J. Sci. Food Agric. 1976, 27, 969-977. [CrossRef]

64. de Freitas, S.T.; do Amarante, C.V.T.; Labavitch, J.M.; Mitcham, E.J. Cellular approach to understand bitter pit development in apple fruit. Postharvest Biol. Technol. 2010, 57, 6-13. [CrossRef]

65. Jemric, T.; Fruk, I.; Fruk, M.; Radman, S.; Sinkovic, L.; Fruk, G. Bitter pit in apples: Pre- and postharvest factors: A review. Span. J. Agric. Res. 2016, 14. [CrossRef]

66. de Freitas, S.T.; do Vamarnet, C.V.T.; Dandekar, A.B.; Mitcham, E.J. Shading affects fresh calcium uptake concentration, bitter pit incidence and other fruit traits in "Greensleeves" apple. Sci. Hortic. 2013, 161, 266-272. [CrossRef]

67. Arrington, M. Optimization of Pollination and Fruit Set in Northern Highbush Blueberry. Ph.D. Thesis, Washington State University, Department of Horticulture, Pullman, WA, USA, December 2017.

68. Silveira, J.P.G.; do Amarante, C.V.T.; Steffens, C.A.; Miquoloto, A.; Katsurayama, J.M. A inibição na síntese de giberelina reduz o crescimento vegetativo em macieiras e proporciona controle de "bitter pit" nos frutos. Rev. Bras. Frutic. 2012, 34, 328-335. [CrossRef]

69. Calvo, G. Control of postharvest disorders in Granny Smith apples by 1-methylcyclopropene 1-MCP application. Rev. Ingestig. Apropecu. 2005, 34, 45-58.

70. Buccheri, M.; Di Vaio, C. Relationship among seed number, quality, and calcium content in apple fruits. J. Plant Nutr. 2004, 27, 1735-1746. [CrossRef]

71. Arrington, M.; DeVetter, L. Foliar applications of calcium and boron do not increase fruit set or yield in northern highbush blueberry (Vaccinium corymbosum). HortScience 2017, 52, 1259-1264. [CrossRef]

(C) 2019 by the authors. Licensee MDPI, Basel, Switzerland. This article is an open access article distributed under the terms and conditions of the Creative Commons Attribution (CC BY) license (http://creativecommons.org/licenses/by/4.0/). 